I/S: A JOURNAL OF IAW AND POLICY FOR THE INFORMATION SOCIETY

\title{
Assessing the Need for More Incentives to Stimulate Next Generation Network Investment
}

\section{ROB FRIEDEN*}

Abstract: Incumbent carriers often vilify the regulatory process as a drain on efficiency and an unnecessary burden in light of robust marketplace competition. Some claim that regulation creates disincentives for investing in expensive next generation networks ("NGNs"), and even for accepting broadband development subsidies if the carrier must provide access to competitors. Without fully assessing the necessity to do so legislators, regulators and judges have accepted the premise that government must create incentives for NGN investment. Incumbent carriers in particular have seized upon the concept of uncertainty as a justification for refraining from making necessary infrastructure investments, despite the onset of declining revenues and market shares in core services. In the worst case scenario, incumbent carriers secure unwarranted and premature deregulation, despite an ongoing need for governments to guard against anticompetitive practices and to promote sustainable competition. Governments also risk providing direct financial subsidies, or creating a regulatory mechanism for indirect subsidies, to stimulate infrastructure investment when no such catalyst is necessary in light of competitive necessity. Once a subsidy mechanism is in place, government may not easily "wean" carriers off such artificial compensation. This article will examine how incumbent carriers in the United States have gamed the incentive creation process for maximum market distortion and competitive advantage. The article suggests

* Pioneers Chair and Professor of Telecommunications and Law, Penn State University, 102 Carnegie Building, University Park, Pennsylvania 16802; email: rmf5@psu.edu. 
that the U.S. government has rewarded incumbents with artificially lower risk, insulation from competition, and partial underwriting of technology projects that these carriers might have undertaken unilaterally. The article also examines the FCC's recently released National Broadband Plan with an eye toward assessing whether the Commission has properly balanced incentive creation with competitive necessity. The article provides recommendations on how governments can calibrate the incentive creation process for maximum consumer benefit instead of individual carrier gain.

\section{INTRODUCTION}

In most nations the current telecommunications sector evidences a hybrid of competitive and noncompetitive markets. Governments strive to find the proper balance between allowing the marketplace to function unfettered where possible, and intervening to compensate for market failures, ${ }^{1}$ such as the inability or unwillingness of telecommunications ventures to provide affordable basic telephone and advanced broadband services, especially in rural areas. Arguably any form of government intervention distorts the competitive playing field, so attempts to remedy market failures should occur only after a determination-corroborated by empirical evidence-that the government ought to regulate, create financial incentives, or facilitate the flow of subsidies from the national treasury, or from one group of consumers to others. ${ }^{2}$

Too often politically adept stakeholders have learned how to game the legislative and regulatory process with an eye toward tilting the competitive playing field by securing unwarranted competitive advantages that were designed to promote the public interest, allow marketplace forces to operate in a competitive environment, or

1 Markets typically reach an equilibrium that balances supply with demand. Governments intervene to remedy situations where the price, quantity, quality, or availability of a service is considered inadequate.

${ }_{2}^{2}$ See Johannes M Bauer, Regulation, Public Policy, and Investment in Communications Infrastructure, 34 TELECOMM. POL'Y, Nos.1-2, 65-79 (Feb. March 2010); Carlo Cambini \& Yanyan Jiang, Broadband Investment and Regulation: A Literature Review, 33 TELECOMM. POL'Y, No. 10-11 559-74 (Nov. Dec. 2009); Jos Huigen \& Martin Cave, Regulation and the Promotion of Investment in Next Generation Networks-A European Dilemma, 32 TELECOMM. POL'y, No. 11, 713-21 ( 2008); Morten Falch, Penetration of Broadband Services-The Role of Policies, 24 TELEMANIACS \& INFORMATICS, No. 4, 246-58 (2007). 
remedy market failures where competition is unsustainable. 3 Incumbent carriers in particular have mastered the legislative and regulatory process and have secured regulatory arbitrage4 opportunities to saddle competitors with comparatively greater government oversight and regulatory burdens, or to secure government-conferred benefits that translate into a comparatively lower cost of doing business. In the United States, incumbent carriers and other stakeholders often succeed in convincing legislators and regulators of the need to create investment incentives, ${ }^{5}$ particularly for costly next generation network ("NGN")6 infrastructure, even though

3 "The instinct to pick outcomes can manifest itself in well-intentioned bureaucratic design, or in regulatory capture by market actors. Even tempting calls for solutions in the name of enabling the market--like creating new or stricter property rights, or allocating resources to the highest bidders-can become a form of selection favoring certain preferred agents over others." Richard S. Whitt \& Stephen J. Schultze, The New "Emergence Economics" of Innovation and Growth, and What It Means for Communications Policy, 7 J. TELECOMM. \& HIGH TECH. L. 217, 307 (Spring 2009). See also Jean-Jacques Laffont \& Jean Tirole, The Politics of Government Decision-Making: A Theory of Regulatory Capture, 106 Q. J. EcoN 1089 (1991). "[T] lobbies-it [has] long been quite cautious, for example, about disagreeing with AT\&T or the television networks.' When it requests submissions, the vast majority come from industry players, not the public. Thus, any regulations it makes would likely be tailored to the desires of the regulated entities and filled with loopholes, rather than designed with the best interests of the public in mind. Congress at least sometimes acts democratically and attempts to represent the public." Matt Getz, "Drowned in Advertising Chatter:" The Case for Regulating Ad Time on Television, 94 GEO. L.J. 1229, 1258 (Apr. 2006) (internal citations omitted).

4 The FCC defines regulatory arbitrage as "businesses making decisions based on regulatory classifications rather than on customers' preferences and innovative and sustainable business plans." Inquiry Concerning High-Speed Access to the Internet Over Cable and Other Facilities, Internet Over Cable Declaratory Ruling; Appropriate Regulatory Treatment for Broadband Access to the Internet Over Cable Facilities, Declaratory Ruling and Notice of Proposed Rulemaking, 17 F.C.C.R. 4798, 4846 (2002). See also, Rob Frieden, Regulatory Arbitrage Strategies and Tactics in Telecommunications, 5 N.C. J.L. \& TECH. 227 (2004).

5 "Next-generation networks will serve as a vibrant engine of economic growth: a job creator the nation desperately needs. To do so, we need to create incentives for those with capital to invest aggressively in our field." Remarks of Commissioner Meredith Attwell Baker, The Proven Way: A Regulatory Approach to Promote the Public Interest by Creating Jobs, Fostering Investment, and Driving Broadband Opportunity, 2010 WL 2343253 (June 10, 2010).

${ }^{6}$ Next generation networks refer to upgrades to existing telecommunications and information services that implement cutting edge technological advances. These networks will provide conduits for delivering high definition, multi-media content and services that require large amounts of bandwidth and extremely fast bitrates. For example, next 
these very same carriers emphasize in other proceedings how robust competition obviates the need for government oversight. In the worst case scenario, incumbent carriers can secure unwarranted and premature deregulation, despite an ongoing need for governments to guard against anticompetitive practices and to promote sustainable competition.7

Governments also risk providing direct financial subsidies, or creating a regulatory mechanism for indirect subsidies, to stimulate infrastructure investment when no such catalyst is necessary in light of competitive necessity. Once a subsidy mechanism is in place, governments may not easily "wean" carriers off of such artificial compensation. In rare instances governments may find some key carriers unwilling to accept subsidies and in turn disinclined to pursue expedited NGN development, as is currently occurring in the U.S. Incumbent carriers do not want to provide interconnection and access to competitors, a legal duty these carriers must bear when operating as common carrier providers of telecommunications networks, ${ }^{8}$ but which does not apply when these carriers offer information services ${ }^{9}$ which include broadband access to the Internet. ${ }^{10}$

This article will examine how stakeholders in the U.S. have exploited the incentive creation process to generate maximum market

generation high definition television may offer three-dimensional format requiring networks capable of delivering 45 million bits per second.

${ }^{7}$ See George S. Ford \& Lawrence J. Spiwak, Set It and Forget It? Market Power and the Consequences of Premature Deregulation in Telecommunications Markets, 1 N.Y.U. J. L. \& BUS. 675 (2005).

8 Telecommunications service is defined as "the offering of telecommunications for a fee directly to the public, or to such classes of users as to be effectively available directly to the public, regardless of the facilities used." 47 U.S.C. $\S 153(46)$. The Communications Act defines telecommunications carrier as "any provider of telecommunications services, except that such term does not include aggregators of telecommunications services (as defined in section 226 of this title). A telecommunications carrier shall be treated as a common carrier under this chapter only to the extent that it is engaged in providing telecommunications services, except that the Commission shall determine whether the provision of fixed and mobile satellite service shall be treated as common carriage." 47 U.S.C. $\$ 153(44)$.

9 Information service is defined as "the offering of a capability for generating, acquiring, storing, transforming, processing, retrieving, utilizing, or making available information via telecommunications, and includes electronic publishing, but does not include any use of any such capability for the management, control, or operation of a telecommunications system or the management of a telecommunications service." 47 U.S.C. $§ 153(20)$. 
distortion and competitive advantage. It suggests that the U.S. government has rewarded incumbents with artificially lower risk, insulation from competition, and the offer of partial underwriting of technological projects that these carriers otherwise might have undertaken unilaterally. This article also provides recommendations on how governments can calibrate the incentive creation process for maximum consumer benefit and individual carrier gain.

\section{NeXt Generation Network InCENTIVe CREATION IN THE UNited STATES}

The cost and perceived risk in NGN investment have motivated incumbent telecommunications carriers to leverage financial commitments in exchange for government conferred financial incentives. ${ }^{11}$ Despite a significant reduction in revenues accruing from core revenue streams, such as voice telephony, ${ }^{12}$ and despite constant claims that the United States benefits from best in class telecommunications services, ${ }^{13}$ incumbent carriers have not

10 "After a tradition of common carriage in telecommunications, broadband was heavily deregulated-supposedly to stimulate incumbents' investment into broadband infrastructure deployment." Jasper P. Sluijs, Network Neutrality Between False Positives and False Negatives: Introducing a European Approach to American Broadband Markets,62 FED. COMM. L.J. 77, 92 (Jan. 2010).

${ }^{11}$ See, e.g., FCC, Industry Analysis and Technology Division, Wireline Competition Bureau, LOCAL TELEPHONE COMPETITION: STATUS AS OF DECEMBER 31, 2009 (Jan 2011), available at http://www.fcc.gov/Daily_Releases/Daily_Business/2011/dbo111/DOC-304054A1.pdf9. The FCC reports that incumbent wireline carriers provided fewer telephone connections in 2009 than a decade previously. Id. at 13, Table 1, End-User Switched Access Lines and VoIP Subscriptions.

12 With an eye toward providing better fact-based assessments of industry competitiveness, the FCC's most recent report on the wireless marketplace uses a more sophisticated and granular assessment. "[R]ather than reaching an overarching, industry-wide determination with respect to whether there is 'effective competition,' the Report complies with the statutory requirement by providing a detailed analysis of the state of competition that seeks to identify areas where market conditions appear to be producing substantial consumer benefits and provides data that can form the basis for inquiries into whether policy levers could produce superior outcomes." Implementation of Section 6002(b) of the Omnibus Budget Reconciliation Act of 1993, Annual Report and Analysis of Competitive Market Conditions With Respect to Mobile Wireless, Including Commercial Mobile Services, Fourteenth Report, WT Docket No. 09-66, FCC 10-81, ๆ 3 (May 20, 2010), available at http://hraunfoss.fcc.gov/edocs_public/attachmatch/FCC-10-81A1.pdf. The Commission largely disputes previous determinations of robust competition and reports significant concentration of ownership that well exceeds a standard measurement for a highly concentrated industry. "Over the past five years, concentration has increased in the provision of mobile wireless services. The two largest providers, AT\&T, Inc. (AT\&T) and 
aggressively sought to make broadband Internet access a major focus for investment, ${ }^{14}$ even though it constitutes a component in the tripleor quadruple-play bundle of telephony, Internet access, and video programming services incumbents now emphasize.

It appears that providers of Internet access, dominated by incumbent telephone and cable companies providing Digital Subscriber Line and cable modem service, respectively, have not faced a degree of broadband competition ${ }^{15}$ sufficient to force aggressive and ongoing efforts to extend and upgrade wireline network capacity,

Verizon Wireless, have 60 percent of both subscribers and revenue, and continue to gain share (accounting for 12.3 million net additions in 2008 and 14.1 million during 2009)." $I d$. at $\uparrow 4$. The Commission uses the Herfindahl-Hirschman Index to measure wireless industry concentration and reports that the current figure of 2848 exceeds the 1800 figure used by the Department of Justice to identify "highly concentrated" industries. See id. at II 48-55.

${ }_{13}$ "The U. S. wireless market is the most innovative and competitive on the planet." Link Hoewing, The U.S. Is a Leader in Innovation and Adoption for Advanced Broadband Wireless Services, Verizon Policy Blog (Feb. 21, 2011), http://policyblog.verizon.com/BlogPost/779/TheUSIsaLeaderinInnovationandAdoptionfo rAdvancedBroadband WirelessServices.aspx.

14 "On Verizon's earnings call today, chief financial officer John Killian projected capital expenditures to be within the range of $\$ 16.8$ billion and $\$ 17.2$ billion, about level with 2009's capex, but he did qualify where that capex will be spent. Killian said he expected wireline capex to decline significantly, giving Verizon flexibility to invest in other aspects of the business. A major source of that investment will be, not coincidentally, in its wireless business as Verizon pursues its next big growth initiative, 4G." Kevin Fitchard, Gap between Verizon's wireless and wireline arms widens, Connected Planet (Jan. 26, 2010), available at http://connectedplanetonline.com/3g4g/news/verizon-wireless-wireline-gapwidens-0126. "The U.S. broadband industry has not been investing enough to meet this growth in demand. The U.S. international ranking in several measures of broadband connectivity has fallen dramatically over the past decade. There is a growing consensus that the federal government has been overly reliant on free market/private enterprise solutions to our broadband needs, while other nations have been moving forward with government sponsored efforts to promote broadband deployment and use." Comments By EDUCAUSE, Internet 2 and ACUTA, A National Broadband Plan for Our Future, GN Docket No. 09-51, available at

http://www.internet2.edu/government/files/EDUCAUSE_FCCcomments_060809.pdf; See also John Windhausen, Blueprint for Big Broadband, EduCause (Jan. 2008), available at http://net.educause.edu/ir/library/pdf/EPOo801.pdf.

15 For an analysis and criticism of the FCC's broadband statistical compilations, see Rob Frieden, Lies, Damn Lies and Statistics: Developing a Clearer Assessment of Market Penetration and Broadband Competition in the United States, 14 VA. J. L. \& TECH. 100 (2009). 
improve performance and lower prices. ${ }^{16}$ These carriers have emphasized the need to discipline high volume subscribers by imposing caps on content downloads, deliberately slowing heavy volume subscribers' download bitrates and by creating multiple service rates based on the volume of monthly downloads. ${ }^{17}$ While such pricing reduces cross-subsidization from low volume users, it also possibly evidences a strategy designed to ration existing bandwidth rather than pursue network upgrades. ${ }^{18}$

Incumbent carriers, such as AT\&T and Verizon, appear to have constrained NGN investment, because of a perception that the FCC will force them to provide network access to competitors, or because the government has not done enough to create investment incentives. ${ }^{19}$ This strategy, if played successfully, can shift the blame to the government for mediocre broadband market penetration and limited investment in NGNs. Rather than having to explain why their

\footnotetext{
${ }^{16}$ In an FCC workshop presentation, Dave Burstein, Editor and Publisher of the industry newsletter DSL Prime, claimed that in 2009 "[V]irtually no investment to extend broadband" occurred. Dave Burstein, U.S. Broadband Data \& Costs, presented at National Broadband Plan Workshop on Broadband Deployment, Federal Communications Commission (Aug. 12, 2009), available at http://broadband.gov/docs/ws_deployment_unserved/ws_deployment_unserved_under served_Burstein_2.pdf. See also Organization for Economic Co-operation and Development, Criteria for the OECD broadband price collections, http://www.oecd.org/document/1/o,3746,en_2649_34225_39575489_1_1_1_1,oo.html (last visited May 11, 2011).
}

${ }_{17}$ "To control congestion and maintain quality of service standards, operators have changed the timing of some application deliveries, charged end users premium prices for higher speeds and capacity and, in a few instances, disconnected high broadband end users by decreasing the revenue stream to application providers." Babette E.L. Boliek, Wireless Net Neutrality Regulation and the Problem With Pricing: An Empirical, Cautionary Tale, 16 MiCH. TELECOMM. \& TECH. L. REV. 1, 14 (2009).

18 "In response to this bandwidth crunch, a number of providers have opted for complex traffic management or QoS mechanisms to ration limited bandwidth among subscribers." Benjamin Lennett, Dis-Empowering Users vs. Maintaining Internet Freedom: Network Management and Quality of Service (QOS), 18 COMMLAW CONSPECTUS 97, 99 (2009).

19 "The issue is we have to be careful that well-intentioned, high-level policy issues don't turn into burdensome rules and regulations that will just stifle growth and innovation. I mean, that - this is a simple issue for me. I fear that when industry -- not just us, but any company makes capital allocations decisions, if we start out with 2, 3, 4 billion dollars' worth of government mandates that really don't have any reality in how the market works, I worry about that, because that just adds costs, it reduces our incentive to invest in this country, and it affects hiring, and you know all the other things that go with that." Council on Foreign Relations, $A$ Conversation with Ivan Seidenberg, Transcript (Apr. 10, 2010), available at http://www.cfr.org/publication/21840/conversation_with_ivan_seidenberg.html\#. 
capital expenditures so emphasize wireless markets and comparatively scrimp on wireline broadband, incumbent carrier officers have framed the issue in terms of regulatory uncertainty and the need for government to "incentivize" NGN investment. ${ }^{20}$ If incumbents can successfully claim that regulatory uncertainty raises risk and creates disincentives for near-term investment, then the carriers possibly can receive government financial support and deregulatory relief simply by stalling. During this limbo period, the U.S. loses competitive advantages by having a comparatively inferior NGN infrastructure and residents cannot accrue all the potential personal and societal benefits from the information age economy which is driven by ubiquitous, fast and affordable broadband networks. ${ }^{21}$

20 "Thus, as it considers various policy proposals for inclusion in the Plan, the Commission
should carefully consider whether those proposals will incentivize facilities investment and
associated job growth, including deployment of broadband networks where they do not
exist today and upgrades to the capabilities of existing networks to keep pace with ever
increasing traffic volumes and user demands for robust services. And it must also ask
whether such proposals will promote a stable, minimally-regulated environment that
enables service providers to attract and deploy capital in an efficient manner." Comments
of AT\&T, Inc., A National Broadband Plan for Our Future, GN Docket No. o9-51 (June 8,
2009), available at
http://www.att.com/Common/about_us/public_policy/Broadband_NOI_Comments.pdf.

"Consumers are reaping the benefits of policymakers' decisions to increase incentives for all providers to invest in bigger and better broadband networks and services. Investment and deployment in next-generation broadband networks - such as Verizon's FiOS network - is happening at a remarkable pace, and consumers now have more choices than ever before. Given these successes, policymakers should reject efforts to impose new regulations - including common carrier-type requirements such as nondiscrimination - on broadband networks and services. Such network regulation would get in the way of innovation and deter continued investment in new and better broadband networks and services." Verizon, Communications Primer, BROADBAND AND THE FUTURE (Jan. 2009), available at http://responsibility.verizon.com/primer/broadband.html.

21 "Nearly 100 million Americans do not have broadband today. Fourteen million Americans do not have access to broadband infrastructure that can support today's and tomorrow's applications. More than 10 million school-age children do not have home access to this primary research tool used by most students for homework. Jobs increasingly require Internet skills ... [y]et millions of Americans lack the skills necessary to use the Internet. What's more, there are significant gaps in the utilization of broadband for other national priorities. In nearly every metric used to measure the adoption of health information technology (IT), the United States ranks in the bottom half among comparable countries, yet electronic health records could alone save more than $\$ 500$ billion over 15 years. Much of the electric grid is not connected to broadband, even though a Smart Grid could prevent 360 million metric tons of carbon emissions per year by 2030 , equivalent to taking 65 million of today's cars off the road. Online courses can dramatically reduce the time required to learn a subject while greatly increasing course completion rates, yet only 
Remarkably, the regulatory uncertainty that incumbent carriers claim, as to what interconnection and infrastructure sharing obligations U.S. carriers must provide, does not currently exist. In the U.S., most infrastructure sharing and unbundling requirements have been eliminated, ${ }^{22}$ or never applied to NGNs in the first place. ${ }^{23}$ Unlike many nations, which have achieved better broadband market penetration performance, ${ }^{24}$ the U.S. has not relied heavily on carrier subsidies, notwithstanding a $\$ 7$ billion annual subsidy primarily for universal access to basic telephone service. ${ }^{25}$ Only after belatedly

$16 \%$ of public community colleges--which have seen a surge in enrollment--have highspeed connections comparable to our research universities. Nearly a decade after $9 / 11$, our first responders still require access to better communications. Unless we reform our approach to these gaps, we will fail to seize the opportunity to improve our nation, and we will fall behind those countries that do. In fact, other countries already have adopted plans to address these gaps. Connecting America: The National Broadband Plan, $2010 \mathrm{WL}$ $972375{ }^{*} 10$ (March 16, 2010).

22 Review of the Section 251 Unbundling Obligations of Incumbent Local Exchange Carriers, Report and Order and Order on Remand and Further Notice of Proposed Rulemaking, 18 F.C.C.R. 16978, 17028, n.245 (2003) (citations omitted); U.S. Telecom Ass'n v. F.C.C., 359 F.3d 554 (D.C. Cir. 2004) (judgment vacated in part, review dismissed in part); Unbundled Access to Network Elements, Review of the Section 251 Unbundling Obligations of Incumbent Local Exchange Carriers, 20 F.C.C.R. 2533, 2541 (2004) (on remand); Covad Comm.'s Co. v. F.C.C., 450 F.3d 528 (D.C. Cir. 2006) (petition denied).

${ }_{23}$ "In previous orders, the Commission has taken a number of important steps aimed at easing the regulatory requirements for broadband facilities and services. Specifically, in the Triennial Review Order, the Commission determined, on a national basis, that incumbent LECs do not have to unbundle certain broadband elements, including fiber-to-the-home (FTTH) loops in greenfield situations, broadband capabilities of FTTH loops in overbuild situations, the packet-switched capabilities of hybrid loops, and packet switching." Qwest Petition for Forbearance Under 47 U.S.C. § 160(C) From Title II 2nd Computer Inquiry Rules with Respect to Broadband Services, Memorandum Opinion and Order, 23 F.C.C.R. 12260,12265 (2008).

24 The Organization for Economic Co-Operation and Development (“OECD") ranks the United States $18^{\text {th }}$ in terms of fixed wireline broadband subscribers per 100 inhabitants. OECD, Broadband Statistics, Broadband penetration and GDP (June 2010), available at http://www.oecd.org/dataoecd/21/57/39574824.xls. Adding wireless options, the U.S. rank improves to $9^{\text {th }}$. OECD, Broadband Statistics, Fixed and wireless broadband subscriptions per 100 inhabitants (June 2010), available at http://www.oecd.org/dataoecd/21/35/39574709.xls.

${ }^{25}$ For background on the United States' universal service funding system, see Kevin Werbach, Connections: Beyond Universal Service in the Digital Age, 7 J. TELECOMM. \& HIGH TECH. L. 67 (Winter 2009); Brian Regan, Ushering Universal Service Reform: Politically Feasible Legislative Principles, 16 COMMLAW CONSPECTUS 471 (2008); David Gabel, Broadband and Universal Service, 31 TELECOMM. POL'Y 327 (2007); Rob Frieden, Killing With Kindness: Fatal Flaws in the \$6.5 Billion Universal Service Funding Mission 
determining that the U.S. suffers from mediocre broadband access, performance, and affordability did Congress determine the need for direct subsidies of broadband network construction. ${ }^{26}$ Until enactment of the American Recovery and Reinvestment Act of 2009, ${ }^{27}$ which allocated $\$ 7.2$ billion for NGN development, the U.S. government largely endorsed the premise of incumbent carriers that the telecommunications marketplace was robustly competitive and without a need for government intervention. ${ }^{28}$ Additionally,

and What Should Be Done to Narrow the Digital Divide, 24 CARDOZO ARTS \& ENT. L.J. 447 (2006); Krishna P. Jayakar \& Harmeet Sawhney, Universal service: beyond established practice to possibility space, 28 TELECOMM. POL'Y 339, 339 (2004).

26 "With the devastating downturn of the economy last fall, a reexamination of where to invest suddenly very scarce governmental resources was in order. With a new President and Congress willing to turn a crisis into an opportunity, the American Recovery and Reinvestment Act of 2009 (ARRA) was enacted by Congress and signed into law by the President, allocating over $\$ 787$ billion dollars in appropriations to help stimulate the economy. The ARRA was designed as an economic stimulus measure to provide funds to create American jobs through investments in education, healthcare, infrastructure, and small businesses, as well as tax cuts, grants, and other methods.

As part of the ARRA, Congress mandated that the Federal Communications Commission (FCC) develop the nation's broadband strategy to address arguably the country's most significant infrastructure challenge: acceleration of broadband deployment in unserved, underserved and rural areas and to strategic institutions that are likely to create jobs or provide significant public benefit. Under the AARA, the FCC was required to deliver to Congress a National Broadband Plan, by March 17th, 2010, that will detail how the United States can bring broadband's immense potential to all corners of the country, thus improving the American quality of life." Jennifer A. Manner \& Ronnie S. Cho, Broadband in America: Introduction to a New Federal Priority, 19 SPG MEDIA L. \& PoL'Y 5, 7-8 (Spring 2010) (citations omitted).

27 American Recovery and Reinvestment Act of 2009, Pub. L. No. 111-005, 123 Stat. 115.

${ }^{28}$ In 2008 the FCC stated "we find, pursuant to the analytical framework established in prior section 706 reports, that advanced telecommunications capability is being deployed to all Americans in a reasonable and timely fashion." In the Matter of Inquiry Concerning the Deployment of Advanced Telecommunications Capability to All Americans in a Reasonable and Timely Fashion, and Possible Steps to Accelerate Such Deployment Pursuant to Section 706 of the Telecommunications Act of 1996, Fifth Report, 23 F.C.C.R. 9615,9616 (2008). However in its $6^{\text {th }}$ Report the Commission used more granular and appropriate analysis of broadband market penetration in the U.S. and refrained from making broad and summary conclusions about the adequacy and ubiquity of broadband access. "Our analysis of broadband subscribership data and the broadband availability model constructed for the National Broadband Plan indicates that while a substantial majority of Americans have access to broadband connections capable of 'originat[ing] and receiv[ing] high-quality voice, data, graphics, and video telecommunications,' roughly 80 million American adults do not subscribe to broadband at home, and approximately 14 to 
incumbents largely convinced courts ${ }^{29}$ and the FCC that compulsory interconnection and infrastructure sharing with competitors, as required by the Telecommunications Act of 1996,30 created NGN investment disincentives. ${ }^{31}$ Incumbents sponsored research and relentlessly advocated the premise that infrastructure sharing, particularly the terms and conditions mandated by the FCC in its interpretation of the Telecommunications Act's requirements, was "confiscatory" and a "taking" of incumbent carriers' property. ${ }^{32}$ Without ever having to provide concrete empirical evidence that local loop unbundling 33 and other facilities sharing requirements were

24 million Americans remain without broadband access capable of meeting the requirements set forth in section 706." Sixth Report, 25 F.C.C.R. 9556, 9557 (2010).

29 "Each unbundling of an element imposes costs of its own, spreading the disincentive to invest in innovation and creating complex issues of managing shared facilities." U.S. Telecom. Ass'n v. FCC, 290 F.3d 415, 427 (D.C. Cir. 2002).

30 Telecommunications Act of 1996, Pub. L. No. 104-104, 110 Stat. 56 (Feb. 8, 1996).

31 "Further, the Commission recognized that, in order effectively to compete for the provision of broadband services, the BOCs generally would need to upgrade their networks substantially with new fiber technologies. However, because section 271 unbundling obligations create disincentives for the BOCs to make substantial investments in these new fiber technologies, in accord with our nation's policy goals of trying to provide all carriers, including BOCs, with incentives to make such investments, the Commission concluded that forbearance relief was justified." Petition of Qwest Corporation for Forbearance Pursuant to 47 U.S.C. $\S 160(C)$ in the Omaha Metropolitan Statistical Area, Memorandum Opinion and Order, 20 F.C.C.R. 19415, 19468 (2005).

${ }^{32}$ See, e.g., Jerry A. Hausman \& J. Gregory Sidak, A Consumer-Welfare Approach to the Mandatory Unbundling of Telecommunications Networks, 109 YALE L.J. 417 (1999); Thomas M. Jorde, J. Gregory Sidak, \& David J. Teece, Innovation, Investment, and Unbundling, 17 YALE J. ON REG. 1 (2000); Daniel F. Spulber \& Christopher S. Yoo, Access to Networks: Economic and Constitutional Connections, 88 CORNELL L. REV. 885 (2003); Allan T. Ingraham \& J. Gregory Sidak, Mandatory Unbundling, UNE-P, and the Cost of Equity: Does TELRIC Pricing Increase Risk for Incumbent Local Exchange Carriers?, 20 YALE J. ON REG. 389, 404 (2003); Richard A. Epstein, Takings, Commons, and Associations: Why the Telecommunications Act of 1996 Misfired, 22 YALE J. ON REG. 315, 315 (2005).

33 "Local loop unbundling (LLU) is a potentially important option that could allow competitors to use unbundled elements or unbundled services of ... [ [the incumbent's] access network to provide alternative telephone or broadband access services to end-users. Most OECD countries require unbundling. ... Unbundling can create incentives for new investment in broadband access and drive faster deployment of broadband services because it allows less costly access to consumers for alternative broadband service providers. Vigorous competition can be expected to drive prices down towards cost." New Zealand Ministry of Economic Development, Report on Commerce Commission's Local Loop and fixed PDN Unbundling Investigation, File BTP/1/TCOMP/11 (May 5, 2004), 
mandated at below cost, as opposed to rates below that which incumbents would like to have charged and probably could have absent a legislated obligation, 34 incumbents largely convinced U.S. government decision-makers that they must eliminate unbundling requirements and deregulate broadband services. 35

available at http://www.med.govt.nz/pbt/telecom/llu-investigation/ministryreport/ministry-report.pdf.

34 In Verizon Comm.'s Inc. v. FCC, 531 U.S. 1124\ (2001), the Supreme Court rejected incumbent local exchange carriers' arguments that using a theoretical, most efficient cost model, instead of actual historical costs, constituted a taking that violated the Fifth Amendment. The Court noted that no party had disputed any specific rate established by the FCC's forward-looking, long-run incremental cost pricing methodology, and concluded that "[r] egulatory bodies required to set [just and reasonable] rates....have ample discretion to choose methodology." Additionally the Court stated that the Telecommunications Act of 1996 did not specifically require historical costs, particularly in light of its explicit prohibition on the use of conventional "'rate-of-return or other ratebased proceeding' ... which has been identified with historical cost ever since Hope Natural Gas was decided." See also, AT\&T Corp. v. Iowa Util.'s Board, 525 U.S. 366\ (1999) (largely upholding the FCC's implementation of the Congressional mandate contained in Section 251 of the Telecommunications Act of 1996 as a reasonable exercise of its rulemaking authority, including its requirement that ILECs unbundle network elements and offer CLECs the opportunity to pick and choose from an a la carte menu or platform of elements).

35 The FCC has accommodated this campaign by classifying broadband Internet access as a robustly competitive information service. "[T]he characteristics of the broadband market, as well as evidence that facilities-based wireline carriers have incentives to make, and indeed already make, broadband transmission capacity available to ISPs, absent regulation, are factors that influence our analysis in determining whether such regulation is still necessary. Moreover, this regulation can have a significant impact on the ability of wireline platform providers to develop and deploy innovative broadband capabilities that respond to market demands. The record shows that the additional costs of an access mandate diminish a carrier's incentive and ability to invest in and deploy broadband infrastructure investment. We find this negative impact on deployment and innovation particularly troubling in view of Congress' clear and express policy goal of ensuring broadband deployment, and its directive that we remove barriers to that deployment, if possible, consistent with our other obligations under the Act. It is precisely this negative impact on broadband infrastructure that led the Commission to eliminate other broadband-related regulation over the past two years. These factors, when weighed against the benefits of continuing these regulations." Appropriate Framework for Broadband Access to the Internet Over Wireline Facilities, Report and Order and Notice of Proposed Rulemaking, 20 F.C.C.R. 14853, 14877-78 (2005). A "continued obligation to provide any new broadband transmission capability to all ISPs indiscriminately as a common carrier, telecommunications service], and provide advance notice thereof, would reduce incentives to develop innovative wireline broadband capabilities and places wireline broadband at a substantial competitive disadvantage vis-à-vis cable modem and other broadband Internet access service providers." Id. at 14905. 
The FCC regularly shows how well it has gotten the message that it must remove NGN investment disincentives and take affirmative steps to create network investment incentives. For example, in assessing why rural areas in the U.S. suffer from limited and costly broadband service options, the FCC noted that to "help stimulate and sustain demand for broadband services in rural areas, both public and private entities should consider developing consumer education and training initiatives, broadband affordability programs, and other incentives to achieve sustainable penetration rates." ${ }^{6}$ On the matter of stimulating broadband access everywhere, FCC Commissioner Robert McDowell expressed the need for combining incentive creation with even more deregulation:

[I]t is essential that our plan give current and prospective broadband network and service providers the proper incentives to deploy new technologies. We must also provide entrepreneurs with the flexibility to make full use of all available spectrum, including the television white spaces, to backhaul broadband traffic. In order to attract investors to fund the buildout of new networks, we must not engage in rulemakings that produce whimsical regulatory arbitrage. Rather, we must allow market players to succeed or fail on their own merits and not due to the government picking winners and losers. In short, our rules must allow network operators to have a reasonable opportunity to pay back their investors. That's the only way to improve existing networks and build new ones. ${ }^{37}$

\footnotetext{
${ }^{36}$ Bringing Broadband to Rural America: Report on a Rural Broadband Strategy, 24 F.C.C.R. 12791, 12801 (Oct. 19, 2009). "The principles that will protect the open Internet are an essential step to maximize investment and innovation in the network and on the edge of it-by establishing rules of the road that incentivize competition, empower entrepreneurs, and grow the economic pie to the benefit of all." Prepared Remarks of Chairman Julius Genachowski, Preserving a Free and Open Internet: A Platform for Innovation, Opportunity, and Prosperity, presented at The Brookings Inst. (Sept. 21, 2009), available at http://www.hraunfoss.fcc.gov/edocs_public/attachmatch/DOC293568A1.pdf.
}

37 A National Broadband Plan for Our Future, Notice of Inquiry, Statement of Commissioner Robert M. McDowell, 24 F.C.C.R. 4342, 4399-4400 (2009). 
Notwithstanding incumbent carriers' opposition to statutory and regulatory initiatives designed to promote competition, these very same carriers are the primary beneficiaries of financial subsidies designed to promote universal access to affordable basic voice services. ${ }^{38}$ Telecommunications service consumers annually pay carriers, primarily incumbent wireline local exchange telephone companies, over $\$ 7$ billion to provide subsidized basic telephone services to individuals, and both basic and advanced services to schools, libraries, clinics, and hospitals. Despite their claims of robust competition, incumbent carriers are willing to carve out an exemption and tap into universal service initiatives designed to remedy longstanding market failures.

Ironically, most incumbent carriers have refrained from submitting proposals to access a portion of the $\$ 7.2$ billion broadband subsidies, apparently in light of the obligation to operate networks open to competitors like that contemplated in the Telecommunications Act of 1996, but no longer required by the FCC. Incumbent carriers have no problem accepting government subsidies when no major interconnection and nondiscrimination requirements apply, but network neutrality 39 and open access conditions for

\footnotetext{
38 "According to the information provided by the FCC, the top ten recipients of High Cost Program dollars received more than $\$ 6$ billion in subsidies between 2006 and 2008 . Among the 'top-ten' recipients of USF subsidies are large corporations, including AT\&T ( $\$ 1.3$ billion in subsidies), Altel ( $\$ 967$ million), Verizon ( $\$ 915$ million), CenturyTel ( $\$ 870$ million), Telephone and Data Systems, Inc. ( $\$ 55^{8}$ million), Embarq ( $\$ 310$ million), Citizens Communications Company ( $\$ 300$ million), Sprint Nextel ( $\$ 282$ million), Windstream ( $\$ 250$ million), Qwest ( $\$ 233$ million), and America Movil ( $\$ 140$ million)." Memorandum from Chairman Henry A. Waxman to U.S. H.R. Comm. on Oversight and Government Reform, Universal Service Fund High Cost Program Subsidies (July 28, 2008), available at http://yubanet.com/usa/Waxman-Requests-Information-onBillions-in-Universal-Service-Fund-Subsidies.php.

39 For background on the debate over network neutrality, see Mark A. Lemley and Lawrence Lessig, The End of End-to-End: Preserving the Architecture of the Internet in the Broadband Era, 48 UCLA L. REV. 925 (2001); Bill D. Herman, Opening Bottlenecks: On Behalf Of Mandated Network Neutrality, 59 FED. COMM. L.J. 103 (Dec. 2006); Rob Frieden, Internet 3.o: Identifying Problems and Solutions to the Network Neutrality Debate, 1 INT'L J. OF COMM. 461 (2007), available at http://ijoc.org/ojs/index.php/ijoc/article/view/16o/86; Rob Frieden, Network Neutrality or Bias?--Handicapping the Odds for a Tiered and Branded Internet, 29 HASTINGS COMM. \& ENT. L.J. 171 (2007); T. Randolph Beard, Network Neutrality and Industry Structure, 29 HASTINGS COMM. \& ENT L.J. 149 (Winter 2007); Tim Wu and Christopher S. Yoo, Keeping the Internet Neutral? Tim Wu and Christopher Yoo Debate, 59 FED. COMM. L.J. 575 (June 2007); Dan G. Barry, The Effect of Video Franchising Reform on Net Neutrality: Does the Beginning of IP Convergence Mean That It Is Time For Net Neutrality Regulation, 24 SANTA CLARA COMPUTER \& HIGH TECH. L.J. 421 (Jan. 2008);
} 
accepting broadband subsidies appear too onerous. ${ }^{40}$ Perhaps the incumbent carriers are resorting to another type of investment holdout in the expectation that they could secure more favorable terms, including less burdensome nondiscrimination and interconnection requirements.

\section{EVEN AS INCUMBENTS DITHER ON NGN INVESTMENT AND CORE Profit Centers Decline, Wireless Service OfFERs A Sufficient}

OFFSET

If incumbent carriers had to operate in a vigorously competitive marketplace, it would stand to reason that these carriers could not refrain from making the wireless and wireline NGN investments needed to offer the kinds of broadband data services consumers increasingly demand. NGN investment would become even more essential if incumbent carriers' profit margins shrink in light of competition and shifting consumer preferences. Both outcomes have occurred as demand for basic voice telephone service has dropped, as have earnings..$^{41}$ But because consumers increasingly substitute more expensive wireless services for their wireline voice and data communications links, incumbent carriers have not yet suffered

Marvin Ammori, Beyond Content Neutrality: Understanding Content-Based Promotion of Democratic Speech, 61 FED. COMM. L.J. 273 (2009).

40 "As the Aug. 20 deadline nears to apply for $\$ 4.7$ billion in broadband grants, AT\&T, Verizon and Comcast are unlikely to go for the stimulus money, sources close to the companies said. Their reasons are varied. All three say they are flush with cash, enough to upgrade and expand their broadband networks on their own. Some say taking money could draw unwanted scrutiny of business practices and compensation, as seen with automakers and banks that have taken government bailouts. And privately, some companies are griping about conditions attached to the money, including a net-neutrality rule that they say would prevent them from managing traffic on their networks in the way they want." Cecilia Kang, Major Carriers Shun Broadband Stimulus Funds Would Come With Tighter Rules, WASH. POST, Aug. 14, 2009, available at http://www.washingtonpost.com/wp$\mathrm{dyn} /$ content/article/2009/08/13/AR2009081302433.html.

${ }^{41}$ In response to declining wireline revenues, Verizon has aggressively sought to sell its lines located in rural locales. See, e.g., Applications Filed by Frontier Communications Corporation and Verizon Communications Inc. for Assignment or Transfer of Control, WC Docket No. 09-95 FCC 10-87, Memorandum Opinion and Order, 25 F.C.C.R. 5972 (2010)(authorizing transfers that would result in control of 4.8 million access lines changing from Verizon to Frontier in primarily rural and smaller city areas in 14 states in the West, Midwest, and South). 
financially even when significant numbers of customers jettison their wireline service. ${ }^{42}$

The FCC's most current statistics (estimated for 2009) confirm a significant reduction in basic wireline service revenues, offset by an even greater increase in wireless revenues. Revenues for end user wireline local telephone service provided by all carriers amounted to $\$ 70.142$ billion, 43 a lower figure than $\$ 75.042$ billion in 2007, and less than the amount these carriers generated in 1998.44 In contrast, end user wireless local telephone service revenues accrued by all carriers amounted to $\$ 115.505$ billion 45 , a substantial increase over $\$ 33.714$ billion generated in 1998.46

It may come to pass that wireline carriers cannot expect to generate anywhere near current revenues for both local and long distance telephone service. Subscribers can combine Voice over Internet Protocol47 software applications and Internet access service

\footnotetext{
42 For the third quarter in 2010 , wireless service generated $62 \%$ of Verizon's revenues. Heather Struck, Verizon Tops Expecations, Raises Outlook, FORBES.com (Oct. 22, 2010), available at $\mathrm{http} / / \mathrm{www}$.forbes.com/2010/10/22/verizon-earnings-mobile-marketsequities-wireless.html. Verizon's Average Revenue Per User ("ARPU”) for retail wireless service rose to $\$ 51.99$ with retail data ARPU increasing $19 \%$ to $\$ 18.61$ per month. Verizon Wireless, Verizon Communications Reports Continued Strong Growth in Cash Flow, Wireless and FiOS in $3 \mathrm{Q}$ (Oct. 22, 2010), available at http://news.vzw.com/news/2010/10/pr2010-10-22.html. The FCC reports that the average monthly charge for basic wireline telephone service in 2008 was $\$ 50$ and $\$ 92$ for wireless service. Industry Analysis and Technology Division, Wireline Competition Bureau: Trends in Telephone Service, Table 3.2, 3-4 (Sep. 2010), available at: http://www.fcc.gov/Daily_Releases/Daily_Business/2010/db0930/DOC-301823A1.pdf [hereinafter cited as Trends in Telephone Service 2010].

43 Trends in Telephone Service 2010 at Table 15.1, 15-3.

$44 \mathrm{Jim}$ Lande and Kenneth Lynch, Wireline Competition Bureau, Telecommunications Industry Revenues 2007, Table 1 Overview of Telecommunications Industry Revenues, 13 (Sept. 2009), available at http://hraunfoss.fcc.gov/edocs_public/attachmatch/DOC293261A2.pdf.
}

45 Trends in Telephone Service 2010 at Table 15.1, 15-3.

${ }^{46} \mathrm{Id}$. Total telecommunications industry revenues, while flat from 2007 to the forecasted amount of $\$ 299.497$ billion have not declined despite the reduction in wireline revenues. $I d$.

47 Voice over the Internet Protocol ("VoIP") refers to the use of the Internet to carry and deliver on a real time, immediate basis packets of data that correspond to a voice conversation. VoIP services range in quality, reliability and price and can link both computers and ordinary telephone handsets. For technical background on how VoIP works see Intel, White Paper, IP Telephony Basics, available at http://www.intel.com/network/csp/resources/white_papers/407oweb.htm; Susan 
to make telephone calls for a fraction of the current cost. Increasingly, wireless service offers subscribers a ready alternative for all voice and data requirements and incumbent carriers have not balked at making the necessary investments to make this infrastructure capable of handling ever-increasing call volume and bandwidth requirements. ${ }^{48}$

\section{ARe InCUMBENTS Playing a GAME OF ChICKEN?}

Whether indifferent to their loses in wireline subscribers 49 or confident that wireless services will make up for any loses, incumbent telephone companies appear more inclined to bolster their wireless investments with markedly less robust interest in wired broadband. Verizon and AT\&T, for example, have concentrated their wireline investments in urban areas with an emphasis on technologies capable of providing video services..$^{\circ}$ These carriers do not appear concerned that their overall broadband investment may contribute to the nation's mediocre statistical record in terms of broadband market penetration, offered bitrate speeds and affordability.

Spradley and Alan Stoddard, Tutorial on Technical Challenges Associated with the Evolution to VoIP, Presentation to FCC Office of Engineering and Technology; see also, Charles J. Cooper \& Brian Stuart Koukoutchos, Federalism and the Telephone: The Case for Preemptive Federal Deregulation in the New World of Intermodal Competition, $6 \mathrm{~J}$. TELECOMM. \& HIGH TECH. L. 293 (2008).

${ }^{48}$ For example, an expert financial analyst forecasted that AT\&T would increase its wireless capital expenditure by $\$ 2$ billion in 2010. "To answer critics of its network performance, AT\&T announced a startling $\$ 2$ billion boost in 2010 wireless capital spending at its fourth quarter and year end earnings call on January 28. This is an important andvery substantial spending increase." Mark Winther, AT\&T Year End FY2009 Earnings: \$2 Billion More in 2010 Wireless Capex, IDC Link (Feb. 1, 2010), available at http://www.att.com/Common/about_us/files/pdf/IDC_report.pdf. This expert estimates that AT\&T and Verizon allocate over $50 \%$ of their annual capital expenditures to wireless.

49 See Saul Hansell, Verizon Boss Hangs Up on Landline Phone Business, N.Y. Times, Sept. 17, 2009, available at http://bits.blogs.nytimes.com/2009/09/17/verizon-boss-hangs-upon-landline-phone-business/?hpw.

$5^{\circ}$ Verizon recently announced a cessation of further investments in its fiber optic video and broadband access service known as FiOS. "If Verizon Communications Inc. hasn't already started wiring your city or town with its FiOS fiber-optic TV and broadband service, chances are you won't get it." Associated Press, Verizon to Slow FiOS Roll-out, Sell off Midwest and West Coast Services, DigrTAL TRENDS, Mar. 26, 2010, available at http://www.digitaltrends.com/computing/verizon-to-slow-fios-roll-out-sell-off-midwestand-west-coast-services/. 
Though hotly disputed, ${ }^{51}$ broadband development in the U.S. has not achieved global best practices in terms of accessibility, affordability, and other evaluative criteria. Many factors have contributed to the comparatively poor performance including low computer ownership, ${ }^{52}$ a large expanse of rural areas with low population density, 53 high service rates and limited competition in

51 "[T] $]$ here is substantial competition in the provision of Internet access services." AT\&T Inc. and BellSouth Corp., Application for Transfer of Control, Memorandum Opinion and Order, 22 F.C.C.R. 5662, 5724-25 (2007). In 2008 the FCC stated that "advanced telecommunications capability is being deployed to all Americans in a reasonable and timely fashion." Inquiry Concerning the Deployment of Advanced Telecommunications Capability to All Americans in a Reasonable and Timely Fashion, and Possible Steps to Accelerate Such Deployment Pursuant to Section 706 of the Telecommunications Act of 1996, Fifth Report, 23 F.C.C.R 9615, 9616 (2008), available at http://hraunfoss.fcc.gov/edocs_public/attachmatch/FCC-o8-88A1.pdf. On the other hand, the Organization for Economic Co-Operation and Development ranks the U.S. $18^{\text {th }}$ among OECD nations in market penetration per 100 inhabitants for fixed services and $9^{\text {th }}$ including wireless services. See n. 29, infra. The Information Technology \& Innovation Foundation, 2008 ITIF Broadband Rankings also place the U.S.in the $15^{\text {th }}$ position. 2008 ITIF Broadband Rankings, THE INFO. TECH. \& INNOVATION FOUNDATION, available at http://www.itif.org/files/2008BBRankings.pdf. See also, S. Derek Turner, 'Shooting the Messenger' Myth us. Reality: U.S. Broadband Policy and International Broadband Rankings, FREE PRESS, July 2007, available at http://www.freepress.net/files/shooting_the_messenger.pdf; Tim Kelly, International Broadband Benchmarks, Presentation at FCC Workshop: International lessons (Aug. 18, 2009), available at

http://www.broadband.gov/docs/ws_int_lessons/ws_int_lessons_kelly.pdf.

${ }^{2}$ The "U.S. has lower levels of PC ownership. Of 21 OECD nations where data were available, the U.S. ranks $11^{\text {th }}$ in PC ownership. If the U.S. had the level of computer ownership as the average of the top 5 nations, it would rank 5 th in broadband adoption, not 10th." Robert Atkinson, International Lessons For Broadband Policy, Presentation at FCC Broadband Policy Workshop, Aug. 18, 2009, available at http://www.broadband.gov/docs/ws_int_lessons/ws_int_lessons_atkinson.pdf; John Horrigan, Home Broadband Adoption 2009, PEW INTERNET \& AMERICAN LIFE PROJECT, June 17, 2009, available at http://www.pewinternet.org/Reports/2009/10-HomeBroadband-Adoption-2009.aspx.

53 "As many of their fellow citizens in more densely populated parts of the country go online for work, education, entertainment, healthcare, civic participation, and much more, too many rural Americans are being left behind. Rural governments and businesses are missing opportunities to function more efficiently and effectively. Even in rural areas where broadband is available, infrastructure deployment has not kept pace with the growing need for faster and more reliable connectivity. At a time when access to affordable, robust broadband services is a fundamental part of efforts to restore America's economic well-being in both rural and urban areas, we must ensure that this capability is available to open the doors of opportunity for everyone." Fed. Commc'n Comm'n, Bringing Broadband to Rural America: Report on a Rurle Broadband Strategy, 24 F.C.C.R. 12791 (2009). 
some locales, 54 and the failure of the government to articulate and implement a broadband development strategy until release of the National Broadband Plan in 2010. Individuals and groups that dispute conclusions of mediocre broadband market penetration note that U.S. consumers benefit from two facilities-based competitive options, with digital subscriber line ("DSL") and cable modem service having nearly equal market share. 55 They also refute statistical compilations and offer alternatives, noting that the U.S. excels in broader measurements of NGN access and national competitiveness. 56

As early as 2007 the FCC determined that the United States had near complete access to broadband Internet access using a very low two hundred kilobits per second threshold for acceptable download speed and concluding that everyone within a possibly large geographical area represented by a zip code had access if anyone did. 57

54 "Study after study demonstrates that our nation's broadband infrastructure lags
dramatically behind other industrialized nations. In order to reverse this trend, we must
encourage 'third pipe' technologies to provide some at least some challenge to the
cable/telco broadband duopoly in our cities." In the Matter of Implementation of the
Commercial Spectrum Enhancement Act and Modernization of the Commission's
Competitive Bidding Rules and Procedures WT Docket No. 05-211, Order on
Reconsideration of the Second Report and Order, Statement of Commissioner Michael J.
Copps, 21 F.C.C.R. 6703,6727 (2006).

55 “America's consumers are now reaping the rewards of the Administration's pro-investment, deregulatory policies: a vigorous broadband marketplace in which providers using various platforms compete against one another on price, speed, mobility, content, and other service features. Currently available data suggest that broadband availability and subscribership have increased dramatically, and that consumers-including those in rural and remote areas-have more opportunities than ever to choose the broadband solution (i.e., technology, services, and provider) that best suits their needs and budget." Dept. of Commerce, National

Telecommunications and Information Adm., Networked Nation: Broadband In America 2007, Exec. Sum. ii (2008), available at http://www.ntia.doc.gov/reports/2008/NetworkedNationBroadbandinAmerica2007.pdf.

${ }^{56}$ See, e.g., Scott Wallsten, Everything You Hear about Broadband in the U.S. is Wrong, The Progress and Freedom Foundation, Progress on Point, Release 14.13 (June, 2007), available at http://www.pff.org/issues-pubs/pops/pop14.13wallstenOECDbroadband.pdf. The World Economic Forum ranks the U.S. first in global competitiveness. Klaus Schwab, The Global Competitiveness Report 2008-2009, WORLD ECON. FORUM, Oct. 8, 2008, available at http://www.weforum.org/pdf/GCRo9/GCR20092010fullreport.pdf. The World Economic forum ranks the U.S. third in information technology. Irene Mia \& Soumitra Dutta, The Global Information Technology Report 2008-2009, WORLD ECONOMIC FORUM, Mar. 26, 2009, available at http://www.weforum.org/en/initiatives/gcp/Global\%2oInformation\%20Technology\%2oR eport/index.htm.

57 "The presence of high-speed service subscribers was reported in all 50 states, the District of Columbia, American Samoa, Guam, Northern Mariana Islands, Puerto Rico, and the 
The Commission belatedly has committed to generating more granular and credible broadband market penetration statistics and recently acknowledged that up to 24 million Americans lack any broadband option, ${ }^{8} 8$ The Commission also compares the reported data with the goal articulated in its Sixth Broadband Deployment Report of having access at a minimum of $4 \mathrm{mbps}$ download and 1 mbps upload.59 At year-end 2009, 58\% of reportable connections (or $76,594,000$ connections) were slower than $3 \mathrm{mbps}$ in the downstream direction, $12 \%$ (or 16,172 ,0oo connections) were at least 3 mbps in the downstream direction but slower than $6 \mathrm{mbps}$, and $30 \%$ (or $40,382,000$ connections) were at least $6 \mathrm{mbps}$ in the downstream direction. ${ }^{60}$ As measured against the Sixth Broadband Deployment Report goal " $68 \%$ of reportable Internet access service connections (or 90,963,000 connections) in December 2009 were too slow in both the downstream and upstream directions, or too slow in a single direction [.]"61 Notwithstanding the FCC's upbeat interpretation of its compiled statistics, other compilers of broadband penetration have generated a

Virgin Islands, and in over $99 \%$ of the Zip Codes in the United States." INDUSTRY ANALYSIS AND TECHNOLOGY DIVISION, WIRELINE COMPETITION BUREAU, HIGH-SPEED SERVICES FOR INTERNET ACCESS: STATUS AS OF JUNE 30, 2007, at 1 (Mar. 2008), available at http://hraunfoss.fcc.gov/edocs_public/attachmatch/DOC-280906A1.pdf; See also Inquiry Concerning the Deployment of Advanced Telecommunications Capability to All Americans in a Reasonable and Timely Fashion, and Possible Steps to Accelerate Such Deployment Pursuant to Section 706 of the Telecommunications Act of 1996, as Amended by the Broadband Data Improvement Act, Fifth Broadband Deployment Report, FCC 08-88 (June 12, 2008), available at http://hraunfoss.fcc.gov/edocs_public/attachmatch/FCC-o888A1.doc.

$5^{8}$ Inquiry Concerning the Deployment of Advanced Telecommunications Capability to All Americans in a Reasonable and Timely Fashion, and Possible Steps to Accelerate Such Deployment Pursuant to Section 706 of the Telecommunications Act of 1996, as Amended by the Broadband Data Improvement Act, Sixth Broadband Deployment Report, FCC 10129 (July 20, 2010), available at http://hraunfoss.fcc.gov/edocs_public/attachmatch/FCC-10-129A1.doc.

59 See Inquiry Concerning the Deployment of Advanced Telecommunications Capability to All Americans in a Reasonable and Timely Fashion, and Possible Steps to Accelerate Such Deployment Pursuant to Section 706 of the Telecommunications Act of 1996, Amended by the Broadband Data Improvement Act, GN Docket Nos. 09-137, 09-51, Report, 25 FCC Rcd 9556, 9563 (2010).

${ }^{60}$ Industry Analysis and Technology Division, Wireline Competition Bureau, Internet Access Services: Status as of December 31, 20093 (Dec. 2010), available at http://www.fcc.gov/Daily_Releases/Daily_Business/2010/db1208/DOC-303405A1.pdf.

${ }^{61} I d$. at 6. 
far less sanguine assessment of the United States' comparative standing. ${ }^{62}$

Until 2009, the U.S. largely eschewed public sector initiatives to expedite broadband development, based on the view that marketplace forces adequately created incentives for investment and favorable interpretation of market penetration statistics. With the change of presidential administrations, the U.S. government no longer has a "mission accomplished" 63 attitude and now concludes that it must remedy market failure, create incentives for infrastructure investment (particularly in rural areas), do a better job of mapping and benchmarking actual network availability, and subsidize access. Curiously, incumbent carriers have had very little to say about such a major undertaking and most of these carriers have not submitted applications to receive a portion of the available funding.

\section{A. Broadband DeVelopment as Part of a National EConomic DEVELOPMENT STRATEGY}

Both the Obama Administration and a majority of Congress consider broadband development, especially in rural areas, an important element in a national strategy to spur economic development. The American Recovery and Reinvestment Act of 2009 ("ARRA") allocated $\$ 4.7$ billion to the National Telecommunications and Information Administration ("NTIA") 64 and $\$ 2.5$ billion to the Department of Agriculture's Rural Utilities Service ("RUS") program ${ }^{65}$

\footnotetext{
${ }^{62}$ See, e.g. Frieden, supra note 15 at $285-288$.

63 John Kneuer, former Assistant Secretary for Communications and Information and Administrator at the Commerce Department's National Telecommunications and Information Administration, claimed in 2008 that the U.S. "has the most effective multiplatform broadband in the world." Steven Levy, True or False: U.S.'s Broadband Penetration Is Lower Than Even Estonia's, NEWSWEEK, July 24, 2007, available at http://www.newsweek.com/id/33456/page/2.

64 For a summary of NTIA's role in allocating broadband stimulus funding, see Dept. of Commerce, National Telecommunications and Information Adm., American Recovery and Reinvestment Act of 2009, available at http://www.ntia.doc.gov/recovery/index.html.

65 For a summary of RUS's role in allocating broadband stimulus funding, see United States Dept. of Agriculture, Broadband USA, available at, http://broadbandusa.sc.egov.usda.gov/; see also, United States Dept. of Agriculture, Rural Development, available at http://www.rurdev.usda.gov/recovery.html; see also, Broadband Initiatives Program, available at http://broadbandusa.sc.egov.usda.gov/BIPportal/index.htm.
} 
to encourage investment in and use of broadband services by awarding grants, loans, or loan guarantees.

NTIA, in consultation with the FCC, administers the Broadband Technology Opportunities Program ("BTOP") with a mandate to facilitate access to broadband service by consumers residing in underserved areas of the U.S. Additional goals include improving access to and use of broadband service by public safety agencies; stimulating the demand for broadband, economic growth, and job creation; and providing broadband education, awareness, training, access, equipment and support to schools, libraries, medical and healthcare providers, community colleges and other institutions of higher education, as well as other community support organizations. While most of the allocated funds do not have specific beneficiaries, the law authorizes no less than $\$ 200$ million for competitive grants to expand public computer center capacity, primarily at community colleges and public libraries. An additional sum of not less than $\$ 250$ million is allocated for competitive grants proposing innovative programs to encourage sustainable adoption of broadband service. The law also includes funding for auditing and oversight of the funds and allocates up to $\$ 350$ million for the development and maintenance of national broadband penetration maps.

The Department of Agriculture's \$2.5 billion budget supports the Distance Learning, Telemedicine, and Broadband Program with financial grants, loans, or loan guarantees. ARRA requires that $75 \%$ of the area to be served by a project receiving financial support shall be in a rural area without sufficient access to high-speed broadband service to facilitate rural economic growth. ARRA establishes a priority for projects that provide service to the highest proportion of rural residents that do not have access to broadband service and that offer end users a choice of more than one service provider. This program also establishes priority access for the telephone and cable television companies that currently have telecommunications loans, or have previously borrowed money under the RUS program. Additionally, funds from the Department of Agriculture's allocation cannot support any project already receiving funding under the NTIA program.

ARRA also requires the FCC, no later than 1 year after enactment, to provide a Report to Congress containing a national broadband plan. The plan should seek to specify how all people in the U.S. can access broadband capability and should specify benchmarks for meeting that goal. The plan also must include an analysis of the most effective and efficient ways to ensure broadband access using a detailed strategy to ensure affordability including evaluation of ongoing projects and grants. ARRA also requires NTIA to develop and maintain a web- 
based, comprehensive nationwide inventory map of existing broadband service capability and availability in the U.S., with specific information about the geographic reach of specific commercial networks or public providers throughout each state.

The final version of the law lacked definitions for such key words as "unserved," "underserved," "broadband," and "high-speed broadband." This means that the involved government agencies, in consultation with the states and grant seekers, had to establish baseline criteria that could easily include underserved urban areas in addition to remote locales. The law also does not establish a preference for any type of broadband technology, nor does it favor public sector over commercial ventures, except for the preference for existing or previous RUS program borrowers.

\section{B. NATIONAL BROADBANd POLICY}

To meet its statutory deadline for delivering a national broadband plan to Congress, ${ }^{66}$ the FCC launched a Notice of Inquiry ("NOI") ${ }^{67}$ seeking advice from all stakeholders on ways to facilitate and expedite "the build-out and utilization of high-speed broadband infrastructure." 68 The Commission emphasized the following issues:

- The most effective and efficient ways to ensure broadband access for all Americans;

- Strategies for achieving affordability and maximum utilization of broadband infrastructure and services;

- Evaluation of the status of broadband deployment, including the progress of related grant programs; and

- How to use broadband to advance consumer welfare, civic participation, public safety and

\footnotetext{
${ }^{66}$ A National Broadband Plan for Our Future, supra note 27, at 4344.

${ }^{67}$ A National Broadband Plan for Our Future, Notice of Inquiry, GN Docket No. 09-51 24 F.C.C.R. 4342 (2009)[hereinafter cited as Broadband Implementation NOI].
}

68 A National Broadband Plan for Our Future, supra note 27 at 4343. 
homeland security, community development, health care delivery, energy independence and efficiency, education, worker training, private sector investment, entrepreneurial activity, job creation, and economic growth, and other national purposes. 69

An allocation of $\$ 7.2$ billion for broadband infrastructure development will not achieve the congressional goal of nationwide broadband deployment. $7^{\circ}$ Accordingly, the Commission must develop a plan that aims for ubiquitous broadband access with benchmarking to measure progress toward achieving that goal.

The FCC's Notice of Inquiry sought comments on how to define broadband capability, which the Commission had initially set at 200 kbps. ${ }^{71}$ This threshold speed does not support full motion video transmission without significant compression and reduction in screen size. ${ }^{72}$ The NOI also sought comments on what constitutes access to

69 The FCC has launched a series of Public Notices seeking advice on how to implement a broadband development plan. See Public Notices for the Omnibus Broadband Initiative, available at

http://blog.broadband.gov/?ArticleTitle=Public\%2oNotices\%2ofor\%2othe\%20Omnibus\% 2oBroadband\%2oIntiative.

7o See n. 156, infra.

${ }^{71}$ Development of Nationwide Broadband Data to Evaluate Reasonable and Timely Deployment of Advanced Services to All Americans, Improvement of Wireless Broadband Subscribership Data, and Development of Data on Interconnected Voice over Internet Protocol, WC Docket No. 07-38, Report and Order and Further Notice of Proposed Rulemaking, 23 F.C.C.R. 9691 (2008); 23 F.C.C.R. 9800 (2008) (Order on Reconsideration).

${ }^{72}$ In 2008 the FCC updated the broadband reporting speed tiers and created the term "first generation data" to refer to those services with data rates greater than 200 Kbps but less than $768 \mathrm{Kbps}$ in the faster direction, and the term "basic broadband tier 1 " to refer to services equal to or greater than $768 \mathrm{Kbps}$ but less than $1.5 \mathrm{mbps}$ in the faster direction. Subsequent tiers were labeled "broadband tier 2" through "broadband tier 7. ." In the Matter of Development of Nationwide Broadband Data to Evaluate Reasonable and Timely Deployment of Advanced Services to All Americans, Improvement of Wireless Broadband Subscribership Data, and Development of Data on Interconnected Voice Over Internet Protocol (VoIP) Subscribership, Report and Order and Further Notice of Proposed Rulemaking WC Docket No. 07-38, 23 F.C.C.R. 9691 (2008). "As many commenters noted, the range of information transfer capacities included in the current lowest tier of $200 \mathrm{Kbps}$ to $2.5 \mathrm{Mbps}$ captures a wide variety of services, ranging from services capable of transmitting real time video to simple always-on connections not suitable for more than basic email or web browsing activities." Id. at 9700. 
broadband, a factor that combines physical proximity of broadband networks and the ability and willingness of consumers to pay for service. ${ }^{73}$ Because of its benchmarking obligations, the FCC needs to measure progress over time and solicited comments on how to gauge market penetration. The Commission recognized that increased infrastructure diffusion may require government-created incentives, similar to the universal service funding for access to basic telephone services, in addition to marketplace competition. ${ }^{74}$ Government incentives will need to promote efficient and effective use of private and public funds for networks that may include wireless options.

Despite having accepted broadband carriers' claims that where they do and do not provide service constitutes a trade secret, 75 the FCC recognized its statutory duty ${ }^{76}$ to compile market penetration data and to map progress geographically. ${ }^{77}$ The Commission has agreed to examine market penetration by census tract, instead of much larger zip codes, and to report service bitrates in several categories of speed. Additionally, the Broadband Data Improvement Act of $2008^{78}$

\footnotetext{
73 See Broadband Implementation NOI at 4349.

74 See, e.g., In the Matter of Universal Service Reform, Mobility Fund, Notice of Proposed Rulemaking, WT Docket No. 10-208, FCC 10-182, 2010 WL 4059849 (rel. Oct. 14, 2010) (seeks comment on using reserves accumulated in the Universal Service Fund to create a new Mobility Fund designed to improve coverage of current-generation or better mobile voice and Internet service for consumers in areas where such coverage is currently missing, and to do so by supporting private investment); see also Federal-State Joint Board On Universal Service; Lifeline and Link-Up, CC Docket No. 96-45, WC Docket No. 03-109, Order, 25 FCC Red 5079 (2010) (seeking advice from a Federal State Board on whether and how to use universal service funding to support broadband access); In the Matter of Federal-State Joint Board on Universal Service Lifeline and Link Up, CC Docket No. 96-45, WC Docket No. 03-109 FCC 10J-3, Recommended Decision, 2010 WL 4390131 (rel. Nov. 4, 2010) (supporting and recommending policies for expanding universal service funding to include broadband access).
}

75 See Center for Public Integrity v. FCC, 505 F. Supp.2d 106, 112 (D.D.C. 2007) (affirming the FCC decision to prevent disclosure of company specific broadband penetration data).

${ }^{76}$ See 47 U.S.C. § 1301 et seq.

7 See In the Matter of Inquiry Concerning the Deployment of Advanced

Telecommunications Capability to All Americans in a Reasonable and Timely Fashion, and Possible Steps to Accelerate Such Deployment Pursuant to Section 706 of the Telecommunications Act of 1996, as Amended by the Broadband Data Improvement Act, GN Docket No. 09-137, Sixth Broadband Deployment Report , 25 F.C.C.R. 9556 (2010); Seventh Broadband Deployment Notice of Inquiry, GN Docket No. 10-159, FCC 10-148, 2010 WL 3133528 (rel. Aug. 6, 2020).

${ }_{78}$ Pub. L. No. 110-385, 122 Stat. 4097 (codified at 47 U.S.C. $\S \S 1301-04$ ). 
requires the FCC to include an international comparison in its annual broadband report and to conduct a consumer survey of broadband service capability.79 While the Commerce Department, through NTIA, and the Department of Agriculture, through RUS, have broadband stimulus funds to award, the FCC will consult with NTIA to determine the meaning of unserved and underserved areas, as well as the definition of broadband and the non-discrimination and interconnection obligations of grantees. ${ }^{80}$ Additionally, the FCC has

79 Section 103(b) requires the FCC to compare the extent of broadband service capability (including data transmission speeds and price for broadband service capability) in a total of 75 communities in at least 25 countries abroad and to choose communities for the comparison under this subsection in a manner that will offer, to the extent possible, communities of a population size, population density, topography, and demographic profile that are comparable to the population size, population density, topography, and demographic profile of the various communities within the United States.

${ }^{80}$ Congress directed NTIA to consult with this Commission on five specific terms and concepts: 1) the definition of "unserved area," Recovery Act $\S 6001(\mathrm{~b})(1)$ ("The purposes of the [BTOP] are to ... provide access to broadband service to consumers residing in unserved areas of the United States."); see also Conf. Rep. 111-16, at 776 ("The [Recovery Act] does not define such terms as 'unserved area' 'underserved areas' and 'broadband.' The Conferees instruct the NTIA to coordinate its understanding of these terms with the FCC, so that the NTIA may benefit from the FCC's considerable expertise in these matters."). 2) the definition of "underserved area," Recovery Act $\S 6001(b)(2)$ ("The purposes of the [BTOP] are to ... provide improved access to broadband service to consumers residing in underserved areas of the United States."); see also Conf. Rep. 111-16, at 776 .; 3) the definition of "broadband," See generally Recovery Act $\S 6001$; see also Conf. Rep. 111-16, at 776; 4) the non-discrimination obligations that will be contractual conditions of BTOP grants, Recovery Act $\S 6001(j)$ ("Concurrent with the issuance of the Request for Proposal for grant applications pursuant to this section, the Assistant Secretary shall, in coordination with the Commission, publish the non-discrimination and network interconnection obligations that shall be contractual conditions of grants awarded under this section, including, at a minimum, adherence to the principles contained in the Commission's broadband policy statement (FCC 05-15, adopted Aug. 5, 2005).") and 5). the network interconnection obligations that will be contractual conditions of BTOP grants. Recovery Act § 6001(j). See also, Public Notice, Comment Procedures Established Regarding the Commission's Consultative Role in the Broadband Provisions of the Recovery Act, GN Docket No. 09-40, DA 09-668 24 F.C.C.R. 3612 (2009); State Broadband Data and Development Grant Program, Docket No. 0660-ZA29, Notice of Funds Availability, 74 Fed. Reg. 32545, 32555 (July 8, 2009) (NTIA State Mapping NOFA) ("[A]ll awardees agree to cooperate with NTIA and the FCC's national broadband mapping efforts. In particular, awardees agree that ... they will coordinate with and lend reasonable assistance to NTIA and the FCC ... in such parties' efforts to assist the recipients in their data collection or to collect broadband mapping related data directly in the States."). "We also note that the Recovery Act requires the Commission to coordinate with NTLA on the publication of 'non-discrimination and interconnection obligations' that will apply to grants received from NTIA 'including, at a minimum, adherence to the principles contained in the Commission's [Internet Policy Statement]." Broadband Implementation NOI at 4358. 
launched a broadband development website ${ }^{81}$ and blog, ${ }^{82}$ scheduled numerous workshops, ${ }^{83}$ and sought the assistance of universityaffiliated research programs to enhance the quality and scope of its national broadband policy assessment. ${ }^{84}$

\section{NATIONAL BRoAdBand Plan AND MisSion StatemENT}

In March 2010, the FCC released a substantial National Broadband Plan that provides Congress with strategies, goals, and many concrete suggestions for improving broadband access, affordability and network performance. ${ }^{85}$ The Commission reported that as of 2009, nearly 100 million Americans lack broadband at home ${ }^{86}$ and between 14 and 24 million Americans do not have access to broadband even if they want it. ${ }^{87}$ Only $42 \%$ of people with disabilities use broadband at home, ${ }^{88}$ while as few as $5 \%$ of people living on Tribal lands have access. ${ }^{89}$ "Meanwhile, the cost of digital exclusion for the student unable to access the Internet to complete a

\footnotetext{
${ }^{81}$ See National Broadband Plan, http://www.broadband.gov/ (last visited May 11, 2011).

82 See National Broadband Plan Blog, http://blog.broadband.gov/ (last visited May 11, 2011).
}

${ }_{83}$ See National Broadband Plan Workshops, http://www.broadband.gov/workshops.html (last visited May 11, 2011).

${ }^{84}$ See, e.g., Federal Communications Commission, Columbia Institute for Tele-

Information to Conduct Independent Review of Telecom Capital Expenditures to Assist FCC, Public Notice (Aug. 6, 2009), available at

http://hraunfoss.fcc.gov/edocs_public/attachmatch/DOC-292598A1.doc; Harvard's

Berkman Center to Conduct Independent Review of Broadband Studies to Assist FCC,

Public Notice (July 14, 2009), available at

http://hraunfoss.fcc.gov/edocs_public/attachmatch/DOC-291986A1.doc.

${ }_{85}$ Federal Communications Commission, Connecting America: The National Broadband Pland, (rel. Mar. 16, 2010) 2010 WL 972375, available at

http://download.broadband.gov/plan/national-broadband-plan.pdf [hereinafter cited as National Broadband Plan].

${ }^{86}$ National Broadband Plan, 2010 WL 972375 at *2 (West pagination).

${ }^{87}$ Sixth Broadband Deployment Report, 25 F.C.C.R. at 9557.

88 John B. Horrigan, Broadband Adoption and Use In America 3 (2010), available at http://hraunfoss.fcc.gov/edocs_public/attachmatch/DOC-296442A1.pdf.

${ }^{89}$ National Broadband Plan at n.71. 
homework assignment, or for the unemployed worker who can't search for a job online, continues to grow."9o

The Plan's call for action over the next decade includes the following primary goals:

- At least 100 million U.S. homes should have affordable access to actual download speeds of at least 100 megabits per second and actual upload speeds of at least 50 megabits per second. ${ }^{91}$

- The United States should lead the world in mobile innovation, with the fastest and most extensive wireless networks of any nation. ${ }^{92}$

- Every American should have affordable access to robust broadband service, and the means and skills to subscribe if they so choose. 93

- Every American community should have affordable access to at least 1 gigabit per second broadband service to anchor institutions such as schools, hospitals and government buildings. 94

- To ensure the safety of the American people, every first responder should have access to a

\footnotetext{
90 See Public Notice, FCC Sends National Broadband Plan To Congress Plan Details Actions for Connecting Consumers, Economy with 21st Century Networks (rel. March 16, 2010), available at http://hraunfoss.fcc.gov/edocs_public/attachmatch/DOC-29688oA1.doc.

91 See National Broadband Plan at 9.

${ }_{92} I d$.

93 Id. at 10.

94 Id.
} 
nationwide, wireless, interoperable broadband public safety network. 95

- To ensure that America leads in the clean energy economy, every American should be able to use broadband to track and manage their real-time energy consumption. ${ }^{96}$

Without specifying a timetable, the FCC also articulated a number of policy recommendations ${ }^{97}$ that it and other government agencies should pursue with an eye toward stimulating competition and innovation. These include: making more spectrum available for existing and new wireless broadband providers to foster additional wireless-wireline competition at higher speed tiers; 98 collecting and publishing more detailed and accurate data on actual availability, penetration, prices, churn and bundles offered by broadband service providers to consumers and businesses;99 establishing technical broadband performance measurement standards and methodology and a process for updating them by partnering with industry and consumer groups; ${ }^{100}$ measuring and publishing data on actual performance of fixed broadband services; ${ }^{101}$ initiating a rulemaking to determine performance disclosure requirements for broadband;102

$95 \mathrm{Id}$.

${ }_{96} I d$. at 11 .

97 Id. at $35-36$.

${ }^{98} \mathrm{Id}$. at 43 .

99 Id. The Commission identified the following starting tasks: improve current Form 477 data collection; collect location-specific subscribership data; collect price, switching costs, customer churn and market share information; make more data and FCC analyses publicly available; BLS should fully resume its computer and internet use supplement.

${ }^{100} \mathrm{Id}$. at 44. The Commission identified the following specific performance parameters: actual speeds and performance over the broadband service provider's network; and the end-to-end performance of the service; actual speeds and performance at peak use hours; actual speeds and performance achieved with a given probability (e.g., 95\%) over a set time period (e.g., one hour) that includes peak use times; and actual speeds and performance tested against a given set of standard protocols and applications. Id. at 45 .

${ }^{101} I d$. at 45 .

102 Id. at 46. 
developing broadband performance standards for mobile services, multi-unit buildings and small business users; ${ }^{103}$ comprehensively reviewing the Commission's wholesale competition regulations to develop a coherent and effective framework and taking expedited action to ensure widespread availability of inputs for broadband services provided to these user groups; ${ }^{104}$ ensuring that interconnection rates, terms and conditions are just and reasonable;105 working to help carriers retire copper-based facilities; ${ }^{106}$ clarifying interconnection rights and obligations and encouraging the shift to Internet Protocol-based interconnection where efficient; ${ }^{107}$ initiating a proceeding on data roaming; ${ }^{108}$ and ensuring that all multichannel video programming distributors install a gateway device or equivalent functionality in all new subscriber homes and requiring replacement set-top boxes in all homes, starting on or before December 31, 2012. ${ }^{109}$

The National Broadband Plan emphasizes spectrum management reform and finding additional bandwidth that can be auctioned to provide broadband services, albeit not necessarily by market entrants instead of incumbents. The categories of spectrum reform include: ensuring greater transparency concerning spectrum allocation and utilization; expanding incentives and mechanisms to reallocate or repurpose spectrum; making more spectrum available for broadband within the next 10 years; increasing the flexibility, capacity and costeffectiveness of spectrum for point-to-point wireless backhaul services; expanding opportunities for innovative spectrum access models; and taking additional steps to make U.S. spectrum policy more comprehensive. ${ }^{110}$

${ }^{103} I d$. at $47-48$

104 Id. at 48 .

$105 I d$.

${ }^{106}$ Id. at 48-49.

${ }^{107}$ Id. at 49.

107 Id.

${ }^{109} \mathrm{Id}$. at 51-52. The Commission noted the lack of competition in the set top box marketplace, reporting that Motorola and Cisco have a 95\% market share and the alternative to set top boxes, i.e., CableCards serving just 500,000 CableCard representing $1 \%$. Id. at $50-51$.

${ }^{110}$ Id. at 73-105. 
On the matter of improving the infrastructure that could be used by broadband network providers when installing transmission lines and other facilities, the Commission issued a number of recommendations aiming to improve use and maximize shared access to federally owned poles, ducts, conduits, rights of way, and other resources. ${ }^{111}$ The National Broadband Plan also devotes chapters to recommendations on research and development. ${ }^{112}$

The National Broadband Plan also proposes a comprehensive overhaul of the universal service funding mechanism and intercarrier interconnection and compensation arrangements. ${ }^{113}$ The Commission proposes to expand the universal service mission to include broadband with several new funding mechanisms to achieve specific new goals. The Commission also wants to start a multi-phased revamping of universal service funding and the basis by which carriers compensate each other when interconnecting and handing off traffic. In terms of broad goals, the FCC hopes to achieve the following:

${ }^{111} I$ d. at $107-18$.

${ }_{112}$ Id. at 119-32. The R\&D recommendations are set out below: the government should focus broadband R\&D funding on projects with varied risk-return profiles, including a mix of short-term and long-term projects (e.g., those lasting 5 years or longer); Congress should consider making the Research and Experimentation (R\&E) tax credit a long-term tax credit to stimulate broadband R\&D; the federal government should provide ultra-highspeed broadband connectivity to select DoD installations to enable the development of next-generation broadband applications; the National Academy of Sciences and the National Academy of Engineering (National Academies) should develop a research road map to guide federal R\&D funding priorities. NSF should establish an open, multi-location, interdisciplinary research center for broadband, addressing technology, policy and economics. Center priorities should be driven by the agenda identified in the National Academies research road map; NSF, in consultation with the Federal Communications Commission (FCC), should consider funding a wireless testbed for promoting the science underlying spectrum policymaking and a testbed for evaluating the network security needed to provide a secure broadband infrastructure. The FCC should start a rulemaking process to establish more flexible experimental licensing rules for spectrum and facilitate the use of this spectrum by researchers.

${ }_{113}$ See id. at 133-64; see also Connect America Fund, A National Broadband Plan for Our Future, Establishing Just and Reasonable Rates for Local Exchange Carriers, High-Cost Universal Service Support, Developing an Unified Intercarrier Compensation Regime, Federal-State Joint Board on Universal Service, Lifeline and Link-Up, WC Docket No. 1090, GN Docket No. 09-51,WC Docket No. 07-135, WC Docket No. 05-337, CC Docket No. 01-92, CC Docket No. 96-45, WC Docket No. 03-109, Notice of Proposed Rulemaking and Further Notice of Proposed Rulemaking, FCC 11-13, 2011 WL 466775 (rel. Feb. 9, 2011), available at http://hraunfoss.fcc.gov/edocs_public/attachmatch/FCC-11-13A1.doc. 
- Connect 100 million households to affordable 100-megabits-per-second service, building the world's largest market of high-speed broadband users and ensuring that new jobs and businesses are created in America.

- Affordable access in every American community to ultra-high-speed broadband of at least 1 gigabit per second at anchor institutions such as schools, hospitals, and military installations so that America is hosting the experiments that produce tomorrow's ideas and industries.

- Ensure that the United States is leading the world in mobile innovation by making 500 megahertz of spectrum newly available for licensed and unlicensed use.

- Move our adoption rates from roughly 65 percent to more than 90 percent and make sure that every child in America is digitally literate by the time he or she leaves high school.

- Bring affordable broadband to rural communities, schools, libraries, and vulnerable populations by transitioning existing Universal Service Fund support from yesterday's analog technologies to tomorrow's digital infrastructure.

- Promote competition across the broadband ecosystem by ensuring greater transparency, removing barriers to entry, and conducting market-based analysis with quality data on price, speed, and availability.

- Enhance the safety of the American people by providing every first responder with access to a 
nationwide, wireless, interoperable public safety network. ${ }^{114}$

From 2010 to 2011 the Commission proposes a target broadband delivery speed of $4 \mathrm{Mbps}$ download and $1 \mathrm{Mbps}$ upload, to improve Universal Service Fund ("USF") performance and accountability, and to create two funds designed to improve broadband access in underserved areas and via wireless technologies. The Commission also wants to create a glide path for eliminating per-minute interconnection charges while providing carriers the opportunity for adequate cost recovery, and to establish interim solutions to prevent arbitrage opportunities where a venture exploits differences in interconnection rates without possibly even providing service. The Commission anticipates the need for second stage from 2012-2016 and a third stage from 2017-2020 to achieve complete reform.

The National Broadband Plan also addresses adoption and use issues including analysis of the reasons why various segments of society do not use broadband services even when available. While much of the Plan addresses supply side issues, issues such as adoption and use are affected by demand side issues, such as whether an individual has sufficient computer skills and interest in the variety of information, communications and entertainment ("ICE") services available via the Internet. The Commission notes that barriers to adoption and use include the cost of broadband, but also such factors as digital literacy and perceived relevance to an individual's life needs. The Commission's strategies include: addressing cost, digital literacy, accessibility and other relevant factors affecting broadband adoption and use; expanding federal support for regional broadband capacitybuilding, program evaluation and sharing of best practices; and coordinating with Native American Tribes on broadband issues. ${ }^{115}$

In the last major section of the National Broadband Plan, the FCC identifies a number of specific service areas for which broadband can enhance national wellbeing. The specific topics in the Plan are health care, education, energy and the environment, economic opportunity, government performance, civic engagement and public safety. For each of these sectors the FCC identifies significant goals, objectives and recommendations. Lastly, the National Broadband Plan addresses how the FCC and interested parties might track and benchmark

${ }_{114}$ FCC Sends National Broadband Plan to Congress, Mar. 16, 2010, available at $2010 \mathrm{WL}$ 930469.

115 NATIONAL BROADBAND PLAN, supra note 85 at 168. 
progress, particularly in light of current statistics that show the United States lagging in terms of broadband market penetration, performance, and affordability. Recognizing that other nations have pursued more active stewardship and the articulation of a national vision for broadband ${ }^{116}$ the FCC hopes to promote competition across the broadband ecosystem by ensuring greater transparency, removing barriers to entry, and conducting market-based analysis with quality data on price, speed, and availability. The Commission specifically recommends that:

- The Executive Branch should create a Broadband Strategy Council to coordinate the implementation of National Broadband Plan recommendations. ${ }^{117}$

- The Commission should quickly publish a timetable of proceedings to implement plan recommendations within its authority, publish an evaluation of plan progress and effectiveness as part of the annual Section 706 Advanced Services Inquiry, create a Broadband Data Depository, and continue to utilize Broadband.gov as a public resource for broadband information. ${ }^{118}$

- The FCC should publish a Broadband Performance Dashboard with metrics designed to track broadband plan goals. ${ }^{119}$

\footnotetext{
${ }^{116}$ See In the Matter of International Comparison Requirements Pursuant to the Broadband Data Improvement Act, GN Docket No. 09-47, International Broadband Data Report, DA 10-1348, First Report, Aug. 27, 2010, available at 2010 WL 3425286.

${ }_{117}$ Id. at 334 .

${ }_{118} I d$.

119 Id. at 335 .
} 


\section{A. JOINT MISSION STATEMENT}

In a rare bipartisan move, the FCC Commissioners also issued a Joint Statement on Broadband outlining what beliefs they share in terms of how to achieve near ubiquitous access to affordable and fast broadband service. "[W]e all share the following common beliefs:

Every American should have a meaningful opportunity to benefit from the broadband communications eraregardless of geography, race, economic status, disability, residence on tribal land, or degree of digital literacy.

Continuous private sector investment in wired and wireless networks and technologies, and competition among providers, are critical to ensure vitality and innovation in the broadband ecosystem and to encourage new products and services that benefit American consumers and businesses of every size.

Strategic and prudent policies toward public resources like spectrum will benefit all Americans, by meeting current and future needs and by promoting continued innovation, investment, and competition.

The nearly $\$ 9$ billion Universal Service Fund (USF) and the intercarrier compensation (ICC) system should be comprehensively reformed to increase accountability and efficiency, encourage targeted investment in broadband infrastructure, and emphasize the importance of broadband to the future of these programs. ${ }^{120}$

Our Nation should harness the tools of modern communications technology to protect all Americans, including by enabling the development of a nationwide, wireless, interoperable broadband network for the Nation's first responders.

\footnotetext{
${ }^{120}$ Section $6001(\mathrm{k})(2)$ of the ARRA states that: "The national broadband plan required by this section shall seek to ensure that all people of the United States have access to broadband capability." Id. at 3 .
} 
Ubiquitous and affordable broadband can unlock vast new opportunities for Americans, in communities large and small, with respect to consumer welfare, civic participation, public safety and homeland security, community development, health care delivery, energy independence and efficiency, education, worker training, private sector investment, entrepreneurial activity, job creation and economic growth, and other national purposes." 121

The Commission anticipates that it can achieve its goals without the need for more financial allocations from the treasury by conducting more spectrum auctions ${ }^{122}$ and by redirecting universal service funds, currently targeting only basic telephone services, for broadband subsidies in rural and other underserved areas. ${ }^{123}$ Other goals either require no direct funding or lack quantification, e.g., creating financial incentives for broadband investments. ${ }^{124}$

The National Broadband Plan provides a comprehensive road map for government stewardship and vision, two long-neglected components that should complement the entrepreneurial motivations of both incumbent and market entrants. The Commission recognizes the need for light-handed intervention that does not distort competition and private sector initiatives to invest in broadband facilities and services: "Due in large part to private investment and market-driven innovation, broadband in America has improved

121 Joint Statement on Broadband, GN Docket No. 10-66, FCC 10-42, Mar. 16, 2010, available at http://hraunfoss.fcc.gov/edocs_public/attachmatch/FCC-10-42A1.doc.

122 "Given the plan's goal of freeing 500 megahertz of spectrum, future wireless auctions mean the overall plan will be revenue neutral, if not revenue positive. The vast majority of recommendations do not require new government funding; rather, they seek to drive improvements in government efficiency, streamline processes and encourage private activity to promote consumer welfare and national priorities." NATIONAL BROADBAND PLAN, supra note 85 at $\mathrm{XV}$.

${ }^{123} I d$. at 5 .

124 "The United States should continue to support policies that hasten the rollout and uptake of telecommunications technology that bridges the international digital divide. Integrating ICT deployment and utilization into broader regional economic development strategies is as important abroad as it is at home. Policies that support the uptake of telecommunications technologies not only provide incentives for needed connectivity but also allow U.S. innovations to flourish in a rapidly developing world market. In turn, Americans benefit from a parallel stream of innovations coming from abroad." Id. at 60 . 
considerably in the last decade. More Americans are online at faster speeds than ever before. Yet there are still critical problems that slow the progress of availability, adoption and utilization of broadband."125

\section{B. A WORK IN PROGRESS}

The National Broadband Plan represents a thoughtful, albeit belated, recognition that the U.S. government can stimulate both the broadband supply and demand through stewardship and vision. However, the Plan does not signal a major shift in strategy, the infusion of billions of dollars more in subsidies beyond the one time allocation of $\$ 7.2$ billion, or a departure from reliance on marketplace forces to allocate most resources to broadband development. The Plan does make the case for many short- and long-term adjustments in policies, many of which the FCC cannot effectuate unilaterally in light of the need for a legislative mandate, or cooperation with other government agencies and stakeholders. The Plan offers hope that some leaders in the U.S. government now recognize the need to adopt global best practices, many of which require the U.S. government to engage in sophisticated analysis of when to become more involved in broadband development, but also when to remove regulatory underbrush that retards timely and flexible adjustments to the mix of radio spectrum available.

The FCC officially recognizes that broadband means something much faster than $200 \mathrm{kbps}$. The Plan proposes an ambitious "100 squared" goal of having 100 million households with access to 100 Mbps download service by 2020, ${ }^{126}$ with a far less ambitious $4 \mathrm{Mbps}$ service of actual download speed available to nearly all residents as soon as possible. ${ }^{127}$

\footnotetext{
125 See id. at 3. "While we must build on our strengths in innovation and inclusion, we need to recognize that government cannot predict the future. Many uncertainties will shape the evolution of broadband, including the behavior of private companies and consumers, the economic environment and technological advances. As a result, the role of government is and should remain limited. We must strike the right balance between the public and private sectors. Done right, government policy can drive, and has driven, progress." Id. at 5 .

126 "The United States must lead the world in the number of homes and people with access to affordable, world-class broadband connections. As such, 100 million U.S. homes should have affordable access to actual download speeds of at least $100 \mathrm{Mbps}$ and actual upload speeds of at least $50 \mathrm{Mbps}$ by 2020 . This will create the world's most attractive market for broadband applications, devices and infrastructure." Id. at 9.

${ }_{127}$ "An initial universalization target of 4 Mbps of actual download speed and $1 \mathrm{Mbps}$ of actual upload speed, with an acceptable quality of service for interactive applications, would ensure universal access." Id. at 135. The Commission deems this goal "one of the
} 
The National Broadband Plan offers scores of thoughtful and probably positive policy changes, but many of them require coordination among federal agencies, newfound zeal in finding ways to use spectrum with greater efficiency, and the need to make changes quickly. Dislodging the status quo will prove daunting because the Plan offers little new inducements for government agencies to refrain from inefficient spectrum use bordering on hoarding and for incumbent wireline carriers to welcome a shift in universal service funding from narrowband telephone service to broadband. The Plan operates under the flawed presumption that broadband competition exists, or soon will flourish, with particular emphasis on wireless broadband options that currently have failed to match the bitrate deliver speeds of wireline options. ${ }^{128}$ Additionally, the Commission appears content with finding new wireless broadband spectrum for incumbent carriers, without considering whether the scope of competition, as well as broadband access and affordability might be enhanced by reserving some newly available spectrum solely for competitive bidding by market entrants. The Plan avoids addressing network interconnection, neutrality and sharing requirements that other nations have adopted with measureable success.

\section{CAN the FCC Develop a National Broadband Plan Without INCUMBENT CARRIER PARTICIPATION?}

While the U.S. Congress has provided $\$ 7.2$ billion in broadband infrastructure funding, the FCC reports estimates ranging from $\$ 20-$ 350 billion as the complete sum needed to provide nationwide coverage based on different delivery speeds. ${ }^{129}$ Accordingly, the

highest universalization targets of any country in the world." Id. However many nations now have far more ambitious goals for the short and middle term. See id.

${ }^{128}$ Additionally AT\&T, possibly joined by Verizon and other carriers, has abandoned unmetered "all you can eat" data subscriptions replacing them with throughput caps. See, e.g, Nick Bilton, AT\&T Eliminates the Unlimited Data Plan, N.Y. TIMES Bits Blog (June 2, 2010), http://bits.blogs.nytimes.com/2010/06/02/att-eliminates-unlimited-smart phoneand-ipad-data-plan/ (last visited Mar. 11, 2011). A move to metered service differentiates wireless broadband services as compared to wireline options probably triggering greater sensitivity to what and how subscribers download. As subscribers use greater vigilance to conserve bandwidth, such "meter mindfulness" takes away some of the pleasure and serendipity the Web offers.

129 "The incremental cost to universal availability varies significantly depending on the speed of service, with preliminary estimates showing that the total investment required ranging from $\$ 20$ billion for $768 \mathrm{Mbps}-3$ Mbps service to $\$ 350$ billion for $100 \mathrm{Mbps}$ or faster. The cost of providing consumers with a choice of infrastructure providers, and/or 
private sector must invest substantial funds, or the U.S. government will have to substantially increase public funding if the U.S. is to have world class NGNs. Historically, U.S. government agencies have eschewed public/private sector partnerships in infrastructure funding. The two predominant models used in the U.S. place the government in the role as primary underwriter and initial anchor tenant user, or as a possible early subscriber willing to await private sector investment. In the former, the U.S. government incubated and largely financed the first networks that eventually became backbone networks for the Internet. In the latter, the U.S. government secures bids from private contractors offering to construct or configure telecommunications capacity for the requirements of one or more federal agencies.

Absent a decision by incumbent carriers to ramp up their NGN investment unilaterally and abandon what appears to be a boycott of broadband stimulus funding initiatives, it appears that the United States government will have to take further affirmative steps to stimulate investment. Such investment stimulation should not reward incumbents' laggard investment, but instead provide partial support for anyone willing to commit to near term projects. Simply put, incumbent carriers may have alerted decision makers to the need for more proactive involvement, but in responding to this provocation the U.S. government should seek out and partially underwrite undertakings of others willing to act immediately.

\section{A. Adopt Global Best Practices}

While political factors prevent the FCC from embracing some globally proven broadband development policies, there are many initiatives the Commission can undertake without a new legislative mandate. Global best practices, which for the most part occur outside the United States, ${ }^{130}$ offer guidance on how to stimulate both supply of broadband capacity and demand for broadband services, the latter

ensuring that all consumers have access to both fixed and mobile broadband would be significantly higher than these initial estimates." Federal Communications Commission, Broadband Task Force Delivers Status Report On Feb. 17 National Broadband Plan (Sep. 29, 2009), available at

http://www.fcc.gov/Daily_Releases/Daily_Digest/2009/ddo90930.html (last visited Mar. 11, 2011).

${ }_{130}$ See, e.g., Yongsoo Kim, Tim Kelly, and Siddhartha Raja, Global Information and Communication Technologies (GICT) Department, The World Bank, Building broadband: Strategies and policies for the developing world (Jan. 2010), available at http://www.infodev.org/en/Document.756.pdf [hereinafter Building Broadband]. 
largely ignored by the U.S. government until release of the National Broadband Plan. Many nations accept a comparatively more active and interventionist role for government leading to public/private partnerships in NGN projects, ${ }^{131}$ expanding the universal service obligation of carriers to include broadband, ${ }^{132}$ spectrum allocation and other administrative rules favoring market entry and facilities-based competition, structural or functional separation of market dominant carriers into a carriers' carrier wholesaler of capacity and retailer, ${ }^{133}$ and subsidization of broadband networks when incumbent carriers fail to achieve clearly articulated service goals and benchmarks. ${ }^{134}$ Best

${ }^{131}$ See European Commission, Information Society and Media, Preparing Europe'sdigital future, i201o Mid-Term Review, COM(2008) 199, SEC(2008) 470, vol.1 p. 96 (Apr. 2008), available at

http://ec.europa.eu/information_society/eeurope/i201o/docs/annual_report/2008/i201 o_mid-term_review_en.pdf; Commission of the European Communities, Commission Staff Working Document Accompanying Document to the Communication From the Commission to the European Parliament, The Council, The European Economic and Social Committee and The Committee of the Regions, Future networks and the internet, Indexing Broadband Performance COM(2008) 594, SEC(2008) 2516 (Sep. 29, 2008), available at

http://ec.europa.eu/information_society/eeurope/i2010/docs/future_internet/swp_bpi.p df; Organization for Economic Cooperation and Development, OECD Broadband Portal, available at http://www.oecd.org/sti/ict/broadband; Broadband Growth and Policies in OECD Nations (2008), available at http://www.oecd.org/dataoecd/32/57/40629067.pdf.

${ }^{132}$ See, e.g., Heidi Kivekäs, Finnish Communications Regulatory Agency, Regulatory views in Finland, presentation at ETSI TC STQ workshop (July 1, 2009), available at http://portal.etsi.org/docbox/Workshop/2009/200907_STQ/o4RegulatoryViewsFinland _KIVEKAS.pdf; Juha Parantainen, Ministry of Transport and Communications, Finland, presentation at Challenges for FTTB/H in Europe, Berlin, Germany, Mar. 23-24 2009, available at http://www.wik.org/fileadmin/Konferenzbeitraege/2009/Challenges_for_FTTB_H_in_E urope/S5_2_Parantainen_NBAC_WIK_FTTH_Conference2009.pdf (last visited Mar.. 11, 2011); Arno Wirzenius, Telecommunications universal service in Finland, 10 INFO 107120 (2008); Michel Berne, Telecommunications universal service in France, 10 INFO No. $5 / 6,121-137$ (2008).

${ }_{133}$ See Openreach, Keeping the UK Connected, available at http://www.openreach.co.uk/orpg/aboutus/Downloads/web_corp_brochure.pdf (explaining the structural separation of British Telecom).

134 " $[B]$ uilding a high-speed telecommunications network is only the necessary first step in developing a broadband system. A range of policies and programs are needed to promote and universalize the use of this network by supporting the development of services and applications, encouraging users to go online and taking steps towards wider inclusiveness. Consequently, viewing broadband as an ecosystem fits with the growing recognition that government strategies need to develop - pull " measures focused on building demand. Such pull measures can promote digital literacy, establish an enabling environment 
practices result in greater market penetration of broadband services, more widespread availability, lower prices, faster bitrates, and higher monthly downloads.

Regardless of political and economic philosophy, national governments have significant functions in NGN development. Successful strategies have included an expansive governmental role in several areas including:

- Developing a vision and strategy;

- Promoting digital literacy, i.e., the ability to use digital technologies to pursue information, communications and entertainment interests;

- Investing in infrastructure, aggregating demand, and serving as an anchor tenant;

- Fostering facilities-based competition;

- Creating incentives for private investment and disincentives for litigation and other delay tactics;

- Offering electronic government services, including healthcare, education, access to information, and licensing;

- Promoting universal service through subsidies and grants; and

- Revising and reforming governmental safeguards to promote a high level of trust, security, privacy, and consumer protection in NGN services, including electronic commerce.

(including an appropriate legal framework), and foster the development of applications (including local content)." Building Broadband, supra note 129 at 7. 


\section{B. Top/DOWn AND BotTom/Up Stimulation MOdElS}

Broadband development strategies typically fit into two general tactics: 1) government seeks to stimulate the production of broadband facilities and services through incentives and subsidies that increase supply; and/or, 2) government seeks to stimulate end user demand for broadband facilities and services. The U.S. government has focused almost exclusively on supply stimulation, with little attention to demand stimulation that could occur in programs to enhance computer literacy, access, and ownership. For example, the current erate program offers no funds for training teachers and students on how to maximize the value of NGN access.

The Top/Down model emphasizes governments' role in articulating a broadband vision, preferably with input and participation from stakeholders and prospective beneficiaries. In this model, governments articulate a national broadband plan and establish service definitions, goals and ways to measure success. An emphasis on expanding the supply of broadband capacity prompts governments to stimulate access by:

- Expanding universal service obligation to include broadband service;

- Using targeted financial stimulus tools such as grants, subsidies, and tax credits;

- Reallocating spectrum to expand available bandwidth useable for broadband services; and

- Supporting competition from multiple platforms, e.g., retrofitted fixed line telephone networks, cable television plant, wireless, fiber optic links, and the powerline grid.

The FCC has recently evidenced greater appreciation for what it can and should do on the supply side of the NGN development equation. While heretofore it has refrained from revamping the existing universal service funding regime to include broadband beyond e-rate beneficiaries, the Commission has started the process for soliciting help on what a national broadband strategy should be. ${ }^{135}$

135 See, e.g., Proposed 2010 Key Broadband Action Agenda Items, available at http://www.broadband.gov/plan/broadband-action-agenda-items.html. 
The U.S. Departments of Agriculture and Commerce now have funds to disburse. The FCC acknowledges the need to make more spectrum available for wireless broadband services, albeit without any consideration whether to allocate some bandwidth exclusively for market entrants instead of incumbents who could use the spectrum to erect barriers to market entry and to bolster their scale, scope, and market domination rather than stimulate more facilities-based competition. ${ }^{136}$ The FCC has supported access to multiple broadband technologies by mostly deregulating these services with the expectation that sustainable competition will ensue, forcing operators to discount service and upgrade networks aggressively without any external prodding.

Global best practices using the Top/Down model show that legislatures and regulatory agencies outside the U.S. have achieved greater geographical penetration, subscribership, bitrates, and price competition through a more aggressive and interventionist posture. ${ }^{137}$ Nations as diverse as Canada, France, Japan, Korea, and Sweden recognized the national and personal advantages of broadband access soon after the technologies became available. ${ }^{138}$ Decades ago, the governments in these and other countries launched and frequently revised an ambitious national broadband vision and strategy,

\footnotetext{
136 "According to an analysis by The Associated Press, the two telecom companies [AT\&T and Verizon] bid more than $\$ 16$ billion, constituting the vast majority of the overall $\$ 19.6$ billion that was bid in the FCC auction. With Verizon Wireless and AT\&T dominating the auction so completely, hopes that the auction would allow for the creation of a new nationwide wireless service provider were dashed." W. David Gardner, Verizon, AT\&T Big Winners in $700 \mathrm{MHz}$ Auction, INFORMATIONWEEK (Mar. 20, 2008), available at $\mathrm{http}: / /$ www.informationweek.com/news/mobility/showArticle.jhtml?articleID=20690500 o; see also, Saul Hansell, Verizon and AT\&T Win Big in Auction of Spectrum, N.Y. TIMES (Mar. 21, 2008), available at http://www.nytimes.com/2008/o3/21/technology/21auction.html; Federal Communications Commission, Auction $73,700 \mathrm{MHz}$ Band, Fact Sheet, available at http://wireless.fcc.gov/auctions/default.htm?job=auction_factsheet\&id=73.
}

${ }^{137}$ See, e.g., International Telecommunication Union, Developments of Next Generation Networks (NGN): country case studies (2009), available at http://www.itu.int/ITUD/treg/Documentation/ITU-NGNo9.pdf; Partnership on Measuring ICT For Development, CORE ICT INDICATORS 2010 (2010), available at http://new.unctad.org/upload/docs/ICT_CORE-2010.pdf; Organization for Economic-Cooperation and Development,

http://www.oecd.org/document/36/o,3746,en_2649_33703_38690102_1_1_1_1,oo.htm 1; Rob Frieden, Lessons From Broadband Development in Canada, Japan, Korea and the United States, 29 TELECOM. POL'CY, No. 8, 595-613 (Sept. 2005).

${ }^{138}$ See, e.g., Building Broadband, supra note 129, at 28-35. 
including definitions of broadband, and establishment of service goals including national coverage, bitrate, quality of service, and price. Countries evidencing best practices have current goals of achieving near ubiquitous access to broadband networks offering a minimum of $1 \mathrm{Mbps}$ service rising to $100 \mathrm{Mbps}{ }^{139}$ Compare these rates with the fact that the FCC still considers $200 \mathrm{kbps}$ the floor for what constitutes broadband, with higher rates something the Commission now wants to track.

Nations evidencing best practices also have enacted or revised laws and regulatory policy to expand universal service obligation to include broadband service. These nations have achieved near ubiquitous access to basic telephone service without the expense, corruption, administrative red tape, and delays which have occurred in the U.S. Many nations can consider broadband access a necessary and logical extension of the existing basic services access mission without bankrupting subsidy programs, risking "compassion fatigue" among telecommunications users obligated to subsidize the program, and having to create excessive incentives for carriers to participate. Best practices nations increase supply of broadband services through infrastructure funding, investment incentives, such as loan guarantees and tax credits, and grants for NGN research and education. ${ }^{140}$ They

139 The government of Finland expects that by 2010, reasonably priced access to $1 \mathrm{Mbps}$ service will be available nationwide and by year end $2015,99 \%$ of all permanent residences should have access, within 2 kilometers, to an optical fiber or cable network delivering 100 mbps service. Government of Finland, Making Broadband Available to Everyone, The National Plan of Action to Improve the Infrastructure of the Information Society, 26 (2008), available at http://www.lvm.fi/c/document_library/get_file?folderId=57092\&name=DLFE-4311.pdf. "Starting next July, [2010] every person in Finland will have the right to a one-megabit broadband connection, says the Ministry of Transport and Communications. Finland is the world's first country to create laws guaranteeing broadband access." YLE.fi, $1 M b$ Broadband Access Becomes Legal Right (Oct. 14, 2009), available at $\mathrm{http}: / /$ yle.fi/uutiset/news/2009/10/1mb_broadband_access_becomes_legal_right_1080 940.html.

${ }^{140}$ See Berkman Center for Internet \& Society at Harvard University, Next Generation Connectivity: A Review of Broadband Internet Transitions and Policy from around the World (2010), available at http://cyber.law.harvard.edu/pubrelease/broadband/; Organization for Economic Co-Operation and Development, Broadband and the Economy, Ministerial background report prepared for the OECD Ministerial Meeting on the Future of the Internet Economy, Seoul, June 17-18 2009, available at http://www.oecd.org/dataoecd/62/7/40781696.pdf; Christine Qiang, Broadband infrastructure investment in stimulus packages: Relevance for developing countries, available at

http://siteresources.worldbank.org/EXTINFORMATIONANDCOMMUNICATIONANDTE CHNOLOGIES/Resources/282822- 
do not "throw money at the problem" indiscriminately, but instead offer only partial funding, thereby obligating grant-seekers to find supplemental financial support and to aggregate demand among many constituencies. ${ }^{141}$

The U.S. Universal Service Funding program currently allocates most subsidies to incumbent wireline carriers, ${ }^{142}$ taking as a given these carriers' cost estimates. ${ }^{143}$ E-rate beneficiaries create islands of broadband access, which they cannot easily extend into the community, or share with eager users who do not qualify as a school, library, clinic, or hospital. ${ }^{144}$ Remarkably, many state legislatures have expressed open hostility to attempts by municipal governments to invest in NGN infrastructure such as citywide Wi-Fi broadband networks. For example, in Pennsylvania the dominant incumbent carrier, Verizon, lobbied and secured a law that gives the company the

1208273252769/Broadband_Investment_in_Stimulus_Packages.pdf; infoDev, 'What Role Should Governments Play in Broadband Development?', paper prepared for infoDev/OECD workshop on Policy Coherence in ICT for Development (Paris, Sep. 10-11 2009).

${ }^{141}$ See OECD, Directorate for Science, Technology and Industry, Committee For Information, Computer and Communications Policy, Working Party on Communication Infrastructures and Services Policy, Network Developments in Support of Innovation and User Needs, DSTI/ICCP/CISP(2009)2/FINAL (Dec. 2009), available at http://www.oecd.org/officialdocuments/displaydocumentpdf/?cote $=\mathrm{dsti} / \mathrm{iccp} / \mathrm{cisp}$ (2009) 2/final\&doclanguage $=$ en; Rob Frieden, Lessons From Broadband Development in Canada, Japan, Korea and the United States, 29 TELECOMM. POL'Y 8, 595-613 (Sept. 2005).

${ }^{142}$ See Federal Communications Commission Response to United States House of Representatives Committee on Energy and Commerce Universal Service Fund Data Request of April 1, 2009, available at http://energycommerce.house.gov/Press_111/20090605/Request_1.pdf. The top ten recipients of universal service funding in 2008 were: 1 AT\&T Inc. \$426,411,917; 2 Altel Corporation* $\$ 416,352,611$; 3 Verizon Communications Inc. ${ }^{*} \$ 308,643,883$; 4 CenturyTel, Inc. $\$ 278,575,256 ; 5$ Telephone and Data Systems, Inc. \$231,868,852; 6 America Movil $\$ 98,342,646$; 7 Windstream Corporation $\$ 97,073,316$; 8 Embarq $\$ 97,040,569$; 9 Sprint Nextel Corporation $\$ 90,479,434$; and 10 Citizens Communications Company $\$ 81,045,280$.

${ }^{143}$ See Universal Service Administrative Co. Web Page, available at http://www.usac.org/default.aspx.

144 In a move that offers greater use of e-rate subsidized Internet access and the probable scorn of commercial vendors, the FCC in March 2010 decided, on a temporary 18 month basis, to permit schools to allow members of the general public to use the schools' Internet access during non-operating hours. Schools and Libraries Universal Service Support Mechanism, CC Docket No. 02-6, Order and Notice of Proposed Rulemaking, FCC 10-33, Feb. 19, 2010, available at http://hraunfoss.fcc.gov/edocs__public/attachmatch/FCC-1033A1.doc. 
right of first refusal whenever a municipality (other than the city of Philadelphia) seeks to operate a broadband network. ${ }^{145}$

Best practices nations have reallocated spectrum to support wireless broadband options, by determining which frequencies and license holders can make do with less spectrum. For example, the FCC has reduced the total amount of radio spectrum allocated for broadcast television, most recently when the conversion from analog to digital broadcasting facilitated more efficient use. ${ }^{146}$ However, with an eye toward maximizing current revenue, the FCC auctioned off the spectrum to the highest bidder without earmarking any spectrum solely for competitive bidding only by market entrants. ${ }^{147}$ Incumbent carriers acquired the vast majority of the new spectrum ${ }^{148}$ and aggressively opposed the one initiative the FCC undertook to promote access by requiring that the winning bidder for one block of spectrum to allow users to use any technically compatible device for access. ${ }^{149}$

145 Commonwealth of Pennsylvania, House Bill 3o, Amending Title 66 (Public Utilities) of the Pennsylvania Consolidated Statutes, Printer's No. 4778, (Nov. 18, 2004), available at http://www.legis.state.pa.us/cfdocs/billinfo/billinfo.cfm?syear=2003\&sind=o\&body=H\&t ype $=\mathrm{B} \& \mathrm{BN}=0030$.

${ }^{146}$ See, e.g., Third Periodic Review of the Commission's Rules and Policies Affecting the Conversion To Digital Television, Report and Order, 23 FCC Rcd 2994 (2007)

${ }^{147}$ Auction of $700 \mathrm{MHz}$ Band Licenses Closes, Winning Bidders Announced for Auction 73, Public Notice, 23 FCC Rcd 4572 (WTB 2008) and Wireless Telecommunications Bureau Grants $700 \mathrm{MHz}$ Band Licenses, Auction 73, Public Notice, 24 FCC Rcd 2255 (WTB 2009).

$14 \$$ "According to an analysis by The Associated Press, ... [incumbent wireless carriers Verizon and AT\&T] bid more than $\$ 16$ billion, constituting the vast majority of the overall $\$ 19.6$ billion that was bid in the FCC auction. With Verizon Wireless and AT\&T dominating the auction so completely, hopes that the auction would allow for the creation of a new nationwide wireless service provider were dashed." W. David Gardner, Verizon, AT\&T Big Winners in $700 \mathrm{MHz}$ Auction, InformationWeek (Mar. 20, 2008), available at http://www.informationweek.com/news/mobility/showArticle.jhtml?articleID=206905000; see also, Saul Hansell, Verizon and AT\&T Win Big in Auction of Spectrum, N.Y. Times (Mar. 21, 2008), available at http://www.nytimes.com/2008/03/21/technology/21 auction.html; Federal Communications Commission, Auction 73, $700 \mathrm{MHz}$ Band, Fact Sheet, available at http://wireless.fcc.gov/auctions/default.htm?job=auction_factsheet\&id=73.

149 "The Commission ultimately adopted an open platform requirement for licensees in the 700 $\mathrm{MHz}$ Upper C Block. The rules require Upper $700 \mathrm{MHz}$ C-Block licensees to allow customers, device manufacturers, third-party application developers, and others to use or develop the devices and applications of their choice for Upper $700 \mathrm{MHz}$ C-Block networks, provided those devices and applications meet all applicable regulatory requirements and comply with reasonable conditions related to management of the wireless network (i.e., do not cause harm to the network). Further, the Commission prohibited Upper $700 \mathrm{MHz}$ C-Block licensees from disabling features or functionality in handsets where such action is not related to reasonable network management and protection, or compliance with applicable regulatory 
Best practices nations promote broadband fiber optic network deployment, especially into and across rural areas. ${ }^{150}$ They also stimulate competition through broadband services resale, including local loop unbundling, ${ }^{151}$ and shared access to fiber optic lines and rights of way. Such public sector intervention comes across as too intrusive in the U.S., yet these initiatives regularly achieve greater broadband penetration and other evidence of successful NGN deployment. Nations forcing incumbent carriers to restructure their operations, or to share network facilities do not embrace socialism and reject marketplace competition. Unlike the U.S., they recognize that the stakes are too high to allow businesses to game the political and regulatory process with an eye toward extracting ever more market-distorting, government-conferred advantages. Best practices nations do not allow incumbent carriers to delay necessary NGN investment until such time as the nation is disadvantaged competitively in a globally integrated information economy that increasingly relies on broadband networks to function.

In the long term, best practices nations seek to stimulate marketdriven competition, while continuing to track progress. ${ }^{152}$ They

requirements. Subject to these conditions, the auction met the reserve price, and Verizon Wireless won the majority of C-Block licenses." In the Matter of Preserving the Open Internet, GN Docket No. 09-191, Notice of Proposed Rulemaking, 24 F.C.C.R. 13064, 13080-81(2009) (citations omitted); see also, In the Matter of Service Rules for the 698-746, 747-762 and 777$792 \mathrm{MHz}$ Bands, WT 06-150, Second Report and Order, 22 F.C.C.R. 15289 (2007).

150 "For new build fibre deployments, if it is apparent that there is only one telecoms access network then we would expect the operator of that network to provide access to it on a fair, reasonable and non-discriminatory basis through fit for purpose wholesale access products. Our approach applies equally to all new build fibre developments and operators." Ofcom, Next Generation New Build Delivering super-fast broadband in new build housing developments, 1.4 (Sept. 23, 2008), available at http://www.ofcom.org.uk/consult/condocs/newbuild/statement/new_build_statement.p df.

${ }^{151}$ See Christine Zhen-Wei Qiang, Broadband Infrastructure Investment in Stimulus Packages: Relevance for Developing Countries (2009), available at $\mathrm{http}: / /$ siteresources.worldbank.org/EXTINFORMATIONANDCOMMUNICATIONANDTE CHNOLOGIES/Resources/282822-

1208273252769/Broadband_Investment_in_Stimulus_Packages.pdf; Ewan Sutherland, LINK Centre, University of the Witwatersrand Unbundling local loops: global experiences (2007), available at http://link.wits.ac.za/papers/LINK.pdf.

${ }_{152}$ See A.K. Mahan, W.H. Melody Eds., Stimulating Investment in Network Development: Roles for Regulators Case Studies and Research from World Dialogue on Regulation Research Cycle 2 (July 2005); available at http://www.infodev.org/en/Publication.12.html. 
promote facilities-based competition from multiple platforms, including retrofitted fixed line telephone networks, cable television plant, wireless, fiber optic links, and the powerline grid. Additionally, these nations monitor incumbent carrier market share and assess the need for structural separation or other precompetitive regulatory and competition policy (antitrust) initiatives. They support reseller transition to facilities-based competition, and they engage in comprehensive mapping, data collection, statistical reporting and quality of service assessments. With such close monitoring of progress, best practices nations can calibrate deregulation with the state of actual and sustainable facilities-based competition. Where market failures persist, they can calibrate and target subsidies to improve broadband accessibility and affordability in chronically undeserved areas, promote research and development in new broadband technologies, reallocate additional spectrum for broadband services as demand grows and expand the definition of universal service to cover broadband targets.

\section{BotTOM/Up MODELS}

Best practices nations also show an appreciation for the need to stimulate the demand for NGNs and the services they deliver. Bottom/Up models stimulate demand for broadband capacity and Internet-mediated services with government becoming an early adopter of NGN-mediated services and an underwriter of programs designed to enhance digital literacy, i.e., the skills needed to use NGNs for enhancing social and personal utility. Nations evidencing best practices seek to use NGNs to provide e-government and education services, promote creation of digital content, support the acquisition of digital literacy skills by the citizenry, and convene workshops and other outreach campaigns to solicit advice from all stakeholders and constituencies.

Bottom/Up models concentrate on educating individuals and institutions so that they can use broadband technologies for individual and collective gain. Programs designed to promote demand for broadband service combine digital literacy campaigns with other initiatives, such as offering access to computer kiosks, free or subsidized computers for home use and support for the creation of digital content. These models recognize that simply building out infrastructure does not guarantee widespread use unless and until prospective users understand how these networks can offer faster, better, smarter, cheaper, and more convenient solutions to existing wants, needs, and desires. 
Digital literacy campaigns concentrate on devising and using broadband (Internet-mediated) services that enhance access to education, job training, employment searches, telemedicine, and other government services. Unlike supply-side programs, Bottom/Up campaigns can funnel grant money to "community champions" and broadband demand aggregators in addition to carriers. Additionally, governments can enhance users' confidence in using NGNs, which process confidential information, by addressing consumer protection issues, including privacy, network reliability, security and neutrality, and competition policy issues.

\section{CONCLUSION}

Excessive confidence in the virtues of market-driven incentives and investment has convinced decision makers in the U.S. to largely eschew efforts to stimulate investment in NGNs. Only in 2010, as mandated by Congress, has the FCC committed to making a conscientious and thoughtful analysis of broadband development deficiencies in the United States. Previously, near absolute reliance on marketplace resource allocation left the U.S. in a comparatively mediocre position in terms of most measures of progress in broadband deployment.

NGN access can substantially contribute to social and individual welfare in light of the spillover and positive externalities that accrue. ${ }^{153}$ Waiting for private ventures to make all necessary investments delays and possibly reduces the substantial benefits to a nation and its residents. The commercial ventures most able to jumpstart broadband development in the U.S. have refrained from participating not because of reluctance to take public subsidies, e.g., billions annually to support access to narrowband, voice telephone service, but because of their opposition to having to share access and comply with nondiscrimination requirements required of broadband subsidy recipients, as well as their view that their wireless ventures offer greater profitability.

The National Broadband plan refrains from addressing what it will take to force incumbent carriers to embrace broadband development

\footnotetext{
${ }_{153}$ "There is considerable reason to believe that there are in fact significant positive externalities from high-speed broadband and that left to themselves, market forces alone will lead to less investment in broadband than is societally optimal." Robert D. Atkinson, The Information Technology and Innovation Foundation, The Case for a National Broadband Policy, at 6 (June 2007), available at http://www.itif.org/files/CaseForNationalBroadbandPolicy.pdf.
} 
as a key commercial mission. These ventures have achieved extraordinary success in convincing government decision makers that substantial deregulation is necessary in light of efficiently operating competitive telecommunications and information service markets. Only recently has the FCC officially acknowledged that the broadband marketplace may not yet qualify for the deregulated status Congress and the FCC previously deemed appropriate. 